\title{
Qualitative and Quantitative Analysis of Cardiac Progenitor Cells in Cases of Myocarditis and Cardiomyopathy
}

\author{
Marie Gerisch ${ }^{1}$, Jan Smettan ${ }^{2}$, Sabine Ebert ${ }^{1}$, Maria Athelogou ${ }^{3}$, Beate Brand-Saberi ${ }^{4}$, \\ Nick Spindler ${ }^{5}$, Wolf C. Mueller ${ }^{6}$, Shibashish Giri ${ }^{1,7 *+}$ and Augustinus Bader ${ }^{1 * t}$ \\ ${ }^{1}$ Applied Stem Cell Biology and Cell Technology, Biomedical and Biotechnological Center, University of Leipzig, Leipzig, \\ Germany, ${ }^{2}$ Division of Cardiology and Angiology, Department of Internal Medicine, Neurology and Dermatology, University \\ Hospital Leipzig, Leipzig, Germany, ${ }^{3}$ Definiens AG, Munich, Germany, ${ }^{4}$ Department of Anatomy and Molecular Embryology, \\ Institute of Anatomy, Faculty of Medicine, Ruhr-University Bochum, Bochum, Germany, ${ }^{5}$ Department of Orthopedics, Trauma \\ and Plastic Surgery, University Hospital Leipzig, Leipzig, Germany, ${ }^{6}$ Department of Neuropathology, University Hospital \\ Leipzig, Leipzig, Germany, ${ }^{7}$ Department of Plastic and Hand Surgery, University Hospital Rechts der Isar, Munich Technical \\ University, Munich, Germany
}

\section{OPEN ACCESS}

Edited by:

Elena G. Pasyukova, Institute of Molecular Genetics (RAS),

Russia

Reviewed by:

Federico Quaini,

Università degli Studi di Parma, Italy Georgina May Ellison-Hughes,

King's College London,

United Kingdom

*Correspondence: Shibashish Gir

shibashish.giri@bbz.uni-leipzig.de Augustinus Bader

Augustinus.bader@bbz.uni-leipzig.de

${ }^{\dagger}$ These authors have contributed equally to this work

Specialty section:

This article was submitted to Genetics of Aging,

a section of the journal

Frontiers in Genetics

Received: 12 September 2017 Accepted: 16 February 2018 Published: 06 March 2018

Citation:

Gerisch M, Smettan J, Ebert S, Athelogou M, Brand-Saberi B, Spindler N, Mueller WC, Giri S and Bader A (2018) Qualitative and Quantitative Analysis of Cardiac

Progenitor Cells in Cases of Myocarditis and Cardiomyopathy. Front. Genet. 9:72

doi: 10.3389/fgene.2018.00072
We aimed to identify and quantify $\mathrm{CD}_{117}{ }^{+}$and $\mathrm{CD} 90^{+}$endogenous cardiac progenitor cells (CPC) in human healthy and diseased hearts. We hypothesize that these cells perform a locally acting, contributing function in overcoming medical conditions of the heart by endogenous means. Human myocardium biopsies were obtained from 23 patients with the following diagnoses: Dilatative cardiomyopathy (DCM), ischemic cardiomyopathy (ICM), myocarditis, and controls from healthy cardiac patients. High-resolution scanning microscopy of the whole slide enabled a computer-based immunohistochemical quantification of CD117 and CD90. Those signals were evaluated by Definiens Tissue Phenomics ${ }^{\circledR}$ Technology. Co-localization of CD117 and CD90 was determined by analyzing comparable serial sections. CD $117^{+} / \mathrm{CD} 90^{+}$cardiac cells were detected in all biopsies. The highest expression of CD90 was revealed in the myocarditis group. CD117 was significantly higher in all patient groups, compared to healthy specimens $(* p<0.05)$. The highest co-expression was found in the myocarditis group $\left(6.75 \pm 3.25 \mathrm{CD} 90^{+} \mathrm{CD} 117^{+}\right.$cells $\left./ \mathrm{mm}^{2}\right)$ followed by ICM $\left(4 \pm 1.89 \mathrm{cells} / \mathrm{mm}^{2}\right)$, $\operatorname{DCM}\left(1.67 \pm 0.58\right.$ cells $\left./ \mathrm{mm}^{2}\right)$, and healthy specimens $\left(1 \pm 0.43\right.$ cells $\left./ \mathrm{mm}^{2}\right)$. We conclude that the human heart comprises a fraction of local $\mathrm{CD} 117^{+}$and $\mathrm{CD} 90^{+}$cells. We hypothesize that these cells are part of local endogenous progenitor cells due to the co-expression of CD90 and CD117. With novel digital image analysis technologies, a quantification of the CD117 and CD90 signals is available. Our experiments reveal an increase of CD117 and CD90 in patients with myocarditis.

Keywords: local cardiac stem/progenitor cells, c-Kit ${ }^{+}\left(\mathrm{CD}_{117^{+}}\right)$cells, $\mathrm{CD}^{+} 0^{+}$cells, myocarditis, cardiomyopathy, human myocardium biopsy

\section{INTRODUCTION}

The World Health Organization reports cardiovascular diseases as the main cause of $29 \%$ of global death each year (Lozano et al., 2012). There are approximately 17.3 million cardiovascularrelated deaths per year worldwide (Townsend et al., 2015). Particularly in the European region, cardiovascular diseases cause 4 million deaths; which is, $45 \%$ of death per year (Townsend et al., 2015). In all countries of Europe, the primary cause of death in women is cardiovascular diseases, 
estimated to be $51 \%$ of all-cause mortality in women. For men, $42 \%$ of deaths are caused by cardiovascular diseases (Townsend et al., 2015).

Due to the profound importance of cardiovascular diseases, the natural endogenous regenerative capacity of the human heart has been a topic of debate for decades. Accumulating evidence over the last decade has suggested that the human heart has the potential to undergo natural regeneration. Locally resident cardiac progenitor or stem cells might play a vital role toward the natural regeneration capacity of the heart. Myocyte proliferation happens to a low extent in the human heart, while enhanced proliferation was observed following injuries of the heart such as myocardial infarction (Beltrami et al., 2001). In addition, the muscle cells of the whole human heart are replaced every 4.5 years (Anversa et al., 2006). Cardiac progenitor cells (CPCs) can replicate in response to some pathological conditions, and they are also able to play an active role in the regeneration of injured parts of the heart (Gonzalez et al., 2008).

Of particular interest are cells with the c-Kit receptor (CD117 or SCFR-stem cell factor receptor) on the surface. Beltrami and colleagues reported the existence of $\mathrm{CD} 117^{+}$cells with characteristics of CPCs (Beltrami et al., 2003). In addition, other researchers described that cardiac $\mathrm{CD} 117^{+}$cells are potential local stem cells, which reside in the human heart (Castaldo et al., 2008; Di Meglio et al., 2010; Sandstedt et al., 2012). Bearzi and colleagues also described the typical stem cell features of the $\mathrm{CD} 117^{+}$cells: they are clonogenic, multipotent, and selfrenewing (Bearzi et al., 2007). An increase in the number of cardiac $\mathrm{CD}_{117^{+}}$cells was observed in several cardiovascular diseases such as heart failure, cardiac hypertrophy, ischemic cardiomyopathy (ICM), acute cardiac injury, and pressure overload (Urbanek et al., 2003, 2005; Castaldo et al., 2008; Kubo et al., 2008; Altarche-Xifró et al., 2009; Itzhaki-Alfia et al., 2009; Rupp et al., 2012).

Nurzynska and colleagues conducted a comparative study of human CPCs in normal and pathological conditions (ischemic heart disease) and confirmed that the differentiation potential of $\mathrm{CD} 17^{+} \mathrm{CPCs}$ of the adult human pathological heart is weak in comparison to healthy cardiac tissue (Nurzynska et al., 2013). Bolli et al. conducted a phase I clinical trial for the clinical implication of $\mathrm{CD}_{1} 17^{+}$stem cells, and interestingly they found an increased cardiac functional capacity, reduced left ventricle scar size, and improved quality of life due to these cells (Bolli et al., 2011). They isolated CD117 ${ }^{+}$cells from $1 \mathrm{~g}$ myocardial tissue during cardiac surgery. They showed that the infusion of 1 million autologous $\mathrm{CD} 117^{+}$stem cells is not associated with noticeable adverse or significant positive effects. Therefore, the study of the anatomy of the human heart and the manner in which pathological states and micro-environmental conditions correlate with the availability of resident CPCs for cardiac tissue regeneration is required to further confirm the presence of local resident progenitor cells as well as for potential clinical strategies for novel forms of cardiac cell therapy by endogenous recruitment. Nevertheless, for progenitor cell detection, additional stem cell markers must be proven. Herein, we focus on the existence of $\mathrm{CD}^{+} 0^{+}$and $\mathrm{CD} 117^{+}$cells as regenerative precursor cells in the human healthy and diseased heart, that are responsible for the activation of endogenous resident progenitor cells toward tissue or cell injury. Previous investigations focused on the detection of $\mathrm{CD}^{+} 0^{+}$and $\mathrm{CD} 117^{+}$ progenitor cells in the human heart along with additional information about biopsy location, diagnosis, patient age, and experimental structure are shown in Table 1. A schematic representation of the human heart provides an overview about biopsy locations used for previous identifications of $\mathrm{CD}^{+} 0^{+}$and CD $117^{+}$endogenous CPCs (Figure 1).

In the current study, we obtained myocardium biopsies from 23 patients with the following diagnoses: dilatative cardiomyopathy (DCM), ICM, myocarditis, and controls from cardiac healthy. The collected material was characterized by immunohistochemistry. Currently, paraffin-based histopathological tissue analysis represents the main conventional method for confirmation of presence or absence of histological markers, grading, or the quantification of stem cells markers in ready tissue sections. Additional quantification of these histopathological slides using an automated image analysis perspective, though providing with more sensitive and qualitative information on the presence of local CPCs in myocardium biopsies, represents a new set of challenges. In our previous studies, we compared immunohistochemical data with an automated image analysis method of digitized slides by Definiens Tissue Studio software (Abraham et al., 2005; Kaemmerer et al., 2014; Neubauer et al., 2016). In several cases, we quantified tissue morphology, staining distribution and intensity of staining, using both automated image analysis and manually performed slides (Abraham et al., 2005; Kaemmerer et al., 2014; Neubauer et al., 2016). Interestingly, in this image analysis, the digital image processing is performed by digitized histological slides, which results in numerous advantages over the conventional immunohistochemical method.

In the present study, we combined a fully automated digital image analysis with conventional histological slides to more sensitively confirm the presence of potential local endogenous $\mathrm{CPCs}$ and to perform a quantitative analysis of the cardiac cell signals in human myocardium biopsies from patients with various cardiac diseases.

\section{MATERIALS AND METHODS}

\section{Patients and Tissue Samples}

Ready sections $(n=69)$ of paraffin-embedded human endomyocardial biopsies from 23 different patients were generously provided after the patient's consent by Prof. K. Klingel (Department of Molecular Pathology, University of Tuebingen, Germany). These biopsies were obtained from cardiac healthy subjects $(n=3)$, patients with myocarditis $(n=$ $3)$, DCM $(n=7)$, or ICM $(n=10)$. The biopsies were derived from the right as well as from the left ventricular myocardium and septum. The mean age of the patients with DCM was 44 years, the average duration of illness amounted 18 years. Patients with ICM had a mean age of 58 years and an average duration of illness of 10 years. In addition, patients with myocarditis had a mean age of 24 years with duration of illness of 1-6 months. 


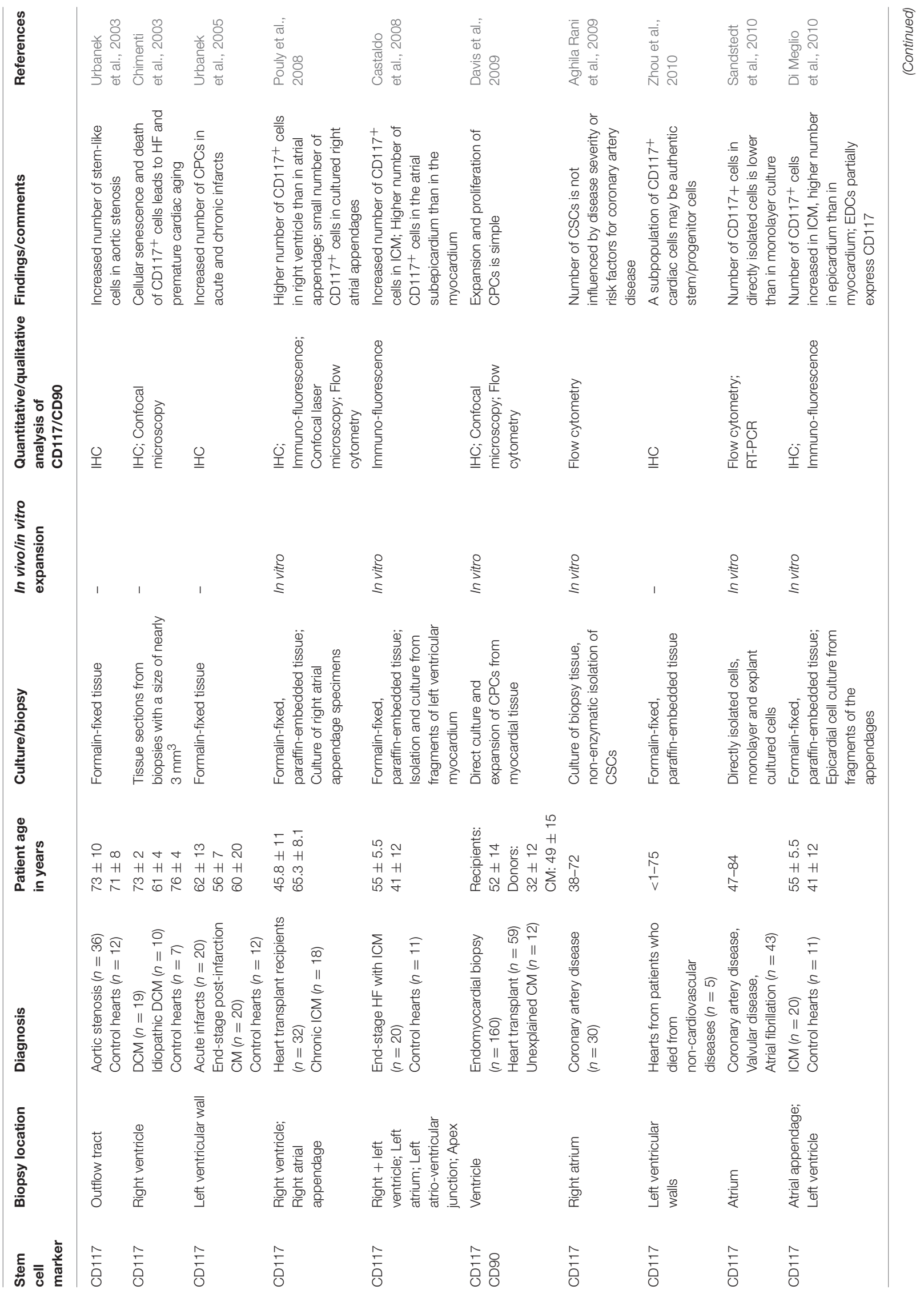




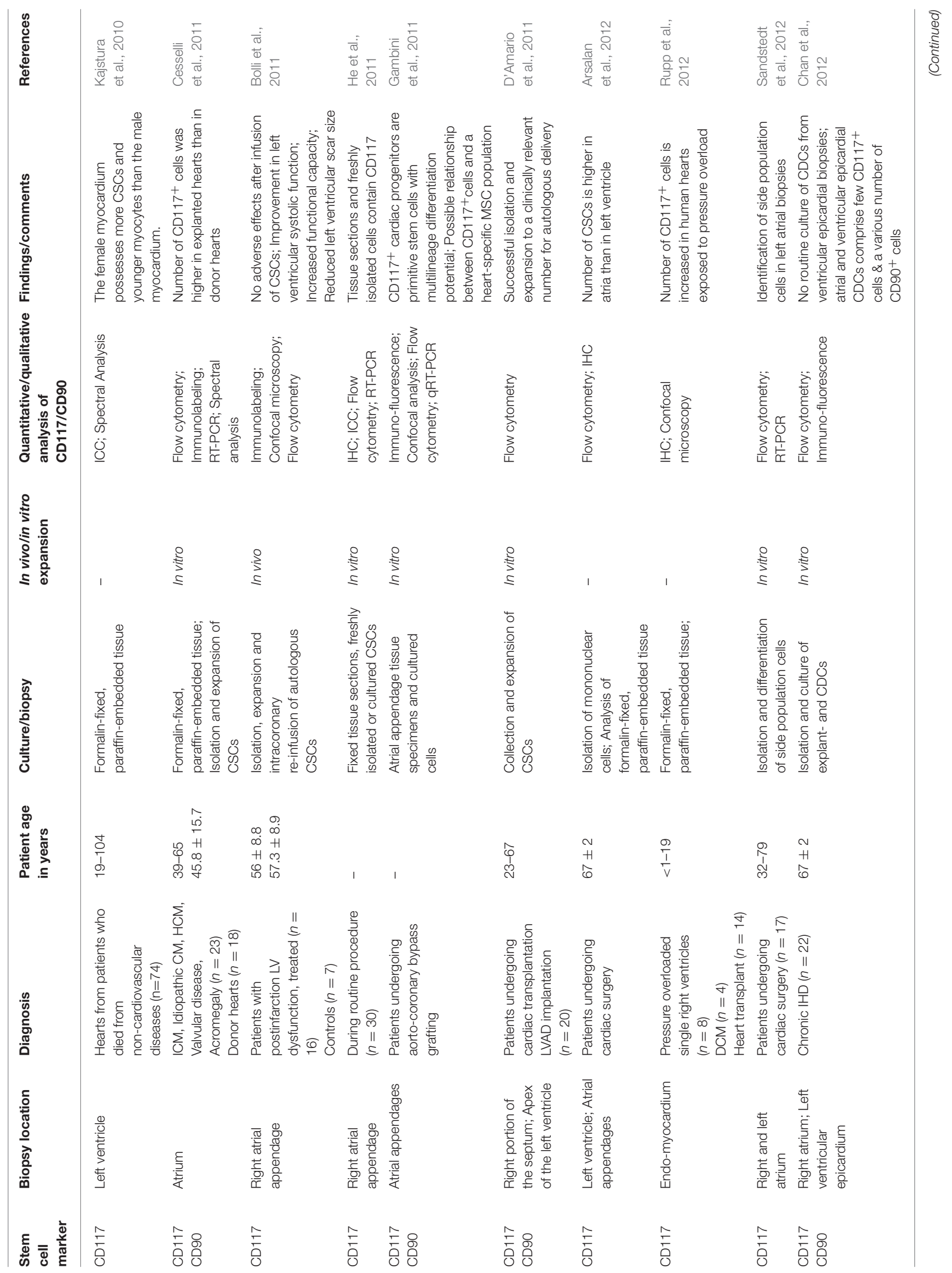




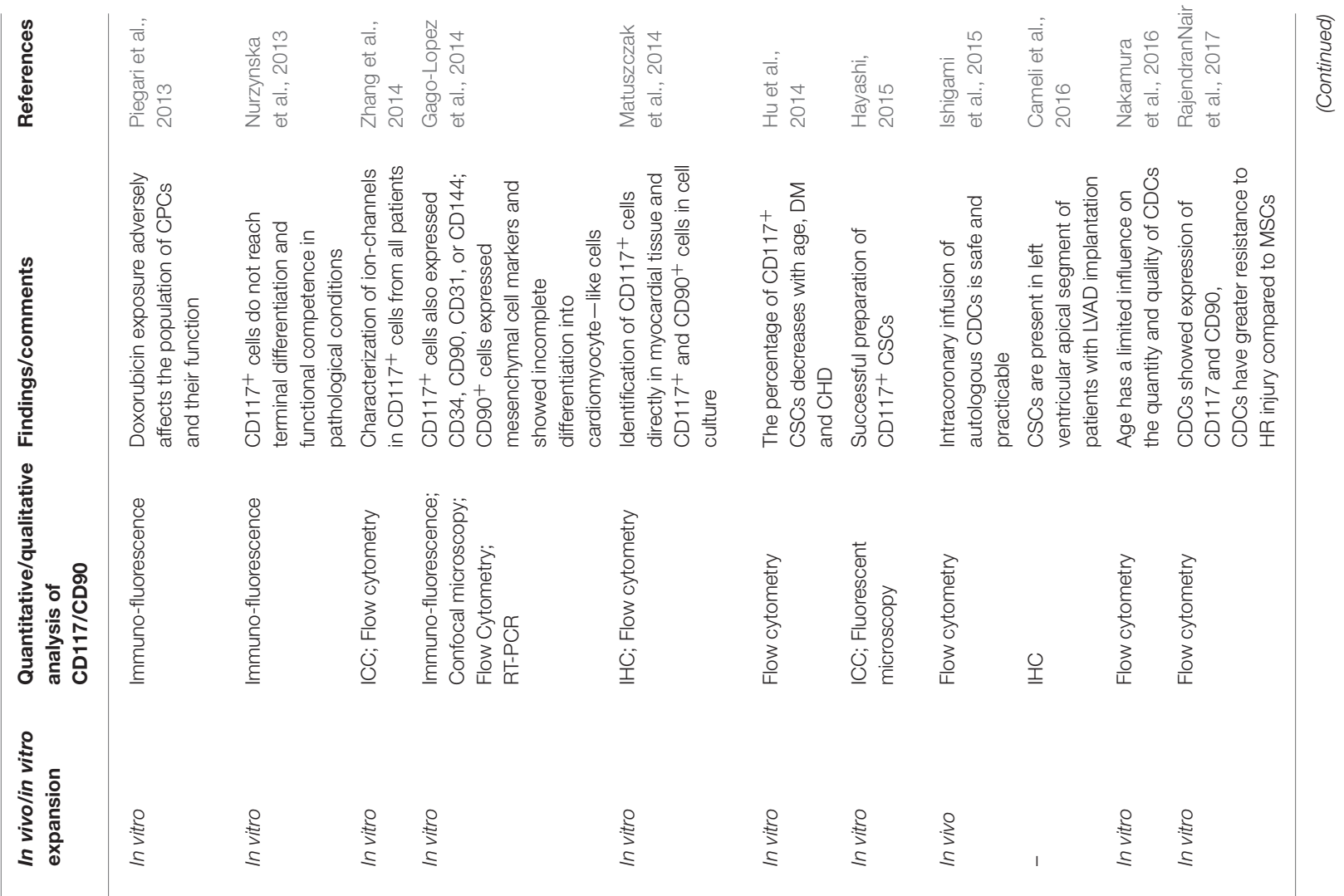

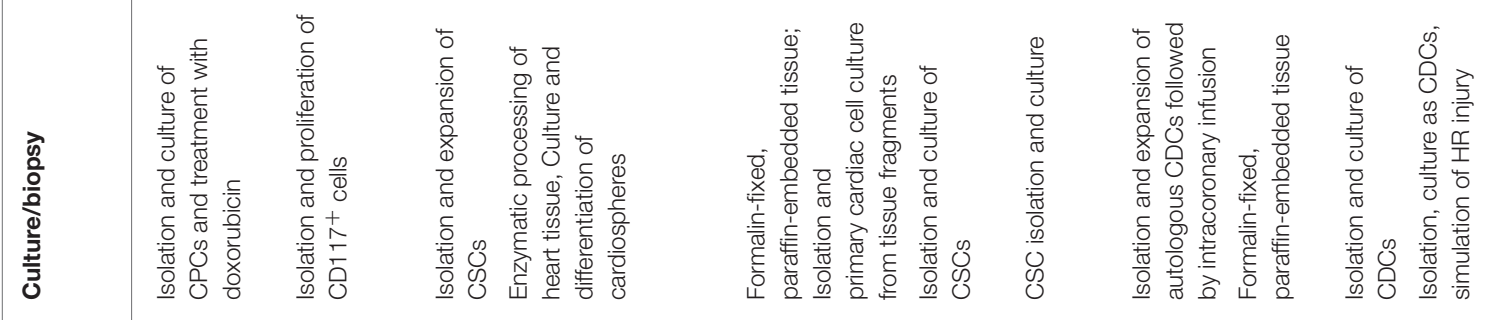
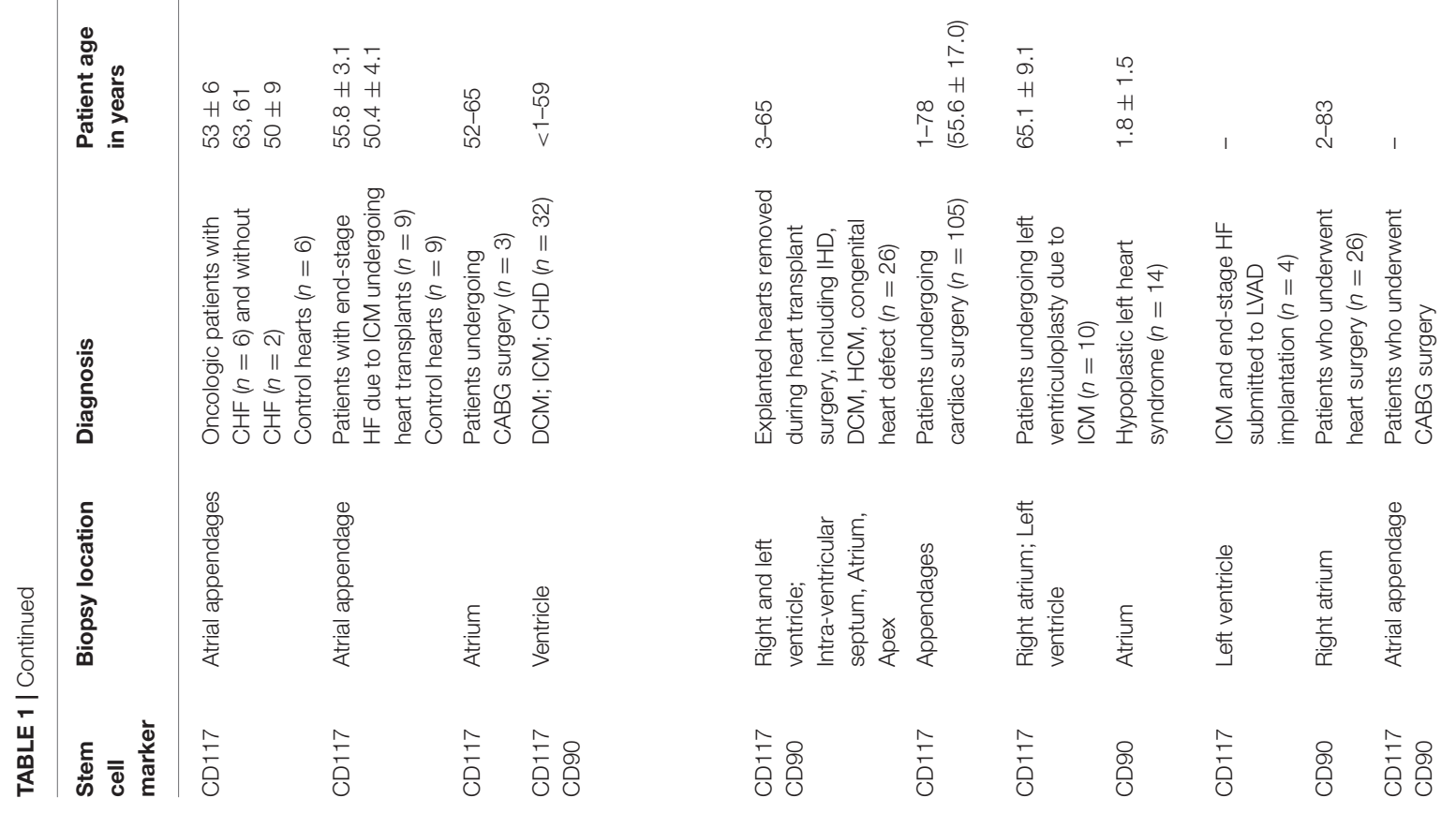


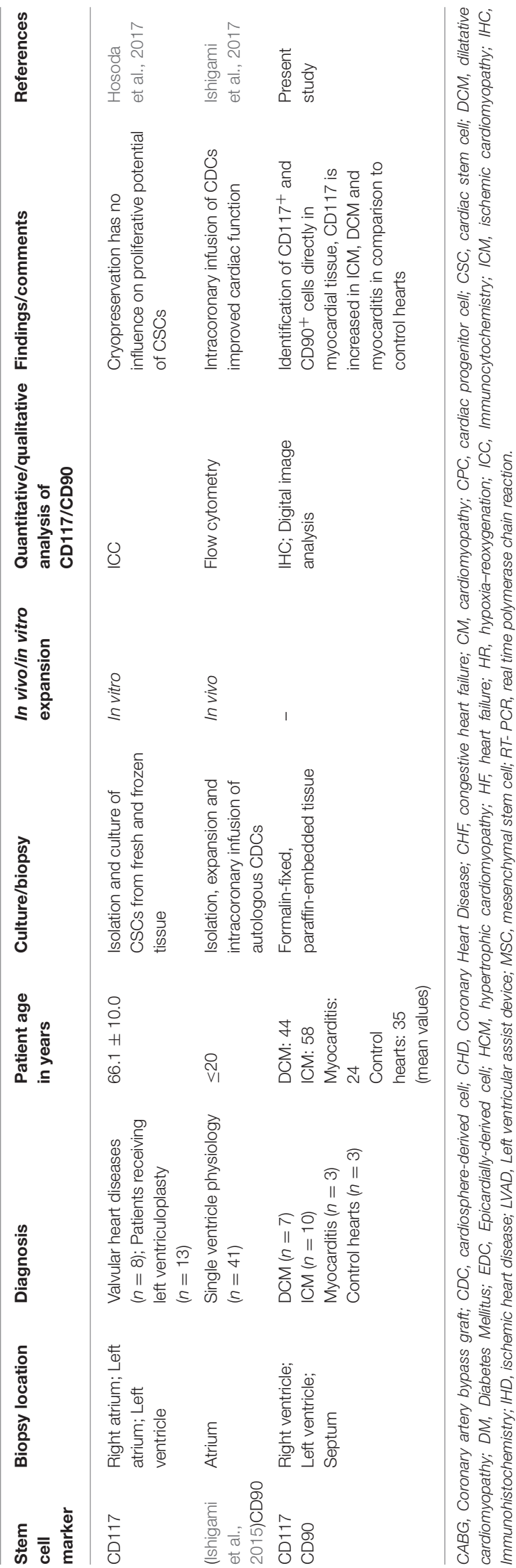

Control patients had a mean age of 35 years. Human skin tissue (University of Leipzig, Department of Orthopedics, Trauma and Plastic Surgery) was used as positive control, negative control, and IgG-control. The investigations were approved by the local ethics committee (050-2010-08032010) and conducted in accordance with the principles of the Declaration of Helsinki World Medical Association (1975). Control tissues also included human cerebellum (University of Leipzig, Neuropathology Department) and kidney (University of Leipzig, Institute of Pathology).

\section{Immunohistochemistry}

Two serial sections of each patient were utilized, one for CD90 staining and the other for CD117 staining, and a partial third one for CD105. The skin specimens were then embedded. The paraffin sections, $8-10 \mu \mathrm{m}$ in thickness were cut with a rotary microtome (model RM2165; Leica Microsystems). The slides were deparaffinized and rehydrated. Afterwards, cells were blocked with $0.6 \% \mathrm{H}_{2} \mathrm{O}_{2}$ in phosphate-buffered saline (PBS; $\mathrm{pH}$ 7.4) and washed in PBS/0.3\% Triton-x. For antigen retrieval, the heat-induced epitope retrieval method was used. The slides were incubated in retrieval solution $(10 \mathrm{mM}$ citrate buffer) in a water bath set to $60^{\circ} \mathrm{C}$ overnight. On day 2 , the slides were washed in PBS and blocked for $30 \mathrm{~min}$ at room temperature with $5 \%$ normal goat serum in PBS. Primary antibodies, in specific, CD90 [anti-CD90/Thy-1 antibody, rabbit monoclonal IgG, clone EPR3133, ab 133350 (dilution 1:100) Abcam Cambridge, UK] and CD117 [anti-c-kit/CD117 antibody, rabbit monoclonal IgG, clone YR145, ab 32363 (dilution 1:50) Abcam Cambridge, UK] were added and incubated overnight at $4^{\circ} \mathrm{C}$. All primary antibodies are particularly suitable for immunohistochemistry of paraffin sections (IHC-P). For supplementary investigations, a further primary antibody was applied on an additional serial section [anti-CD105 antibody, rabbit monoclonal IgG, clone EPR10145, ab 169545 (dilution 1:200) Abcam Cambridge, UK]. Negative control staining was performed whereby the primary antibody was omitted. As isotype control served rabbit monoclonal IgG [clone EPR25A, ab172730 (dilution 1:100) Abcam Cambridge, UK]. The images of the positive and negative controls can be found in the Supplementary Material.

On day 3, the slides were washed in PBS and incubated with the secondary antibody [secondary horseradish peroxidase conjugated goat anti-rabbit IgG $(\mathrm{H}+\mathrm{L}), 111-035-003$ (dilution $1: 100$ in PBS $+1 \%$ goat serum $+1 \%$ human serum), Dianova Jackson Immuno-research Hamburg, Germany], for $45 \mathrm{~min}$ at room temperature, followed by incubation with 3-amino-9ethyl-carbazole (AEC) in sodium acetate buffer $(0.1 \mathrm{~mol} / \mathrm{L}, \mathrm{pH}$ 5.2) containing hydrogen peroxide. After rinsing, the sections were counterstained with hematoxylin Lillie's modification (ready-to-use formulation; DakoCytomation, Copenhagen, Denmark) and mounted in glycergel (Kaiser's glycerol gelatine; Merck KGaA, Darmstadt, Germany).

\section{Image Analysis}

Scanning of the complete slide was performed by Virtual Microscope Olympus VS 120 (Ruhr-University Bochum Faculty 

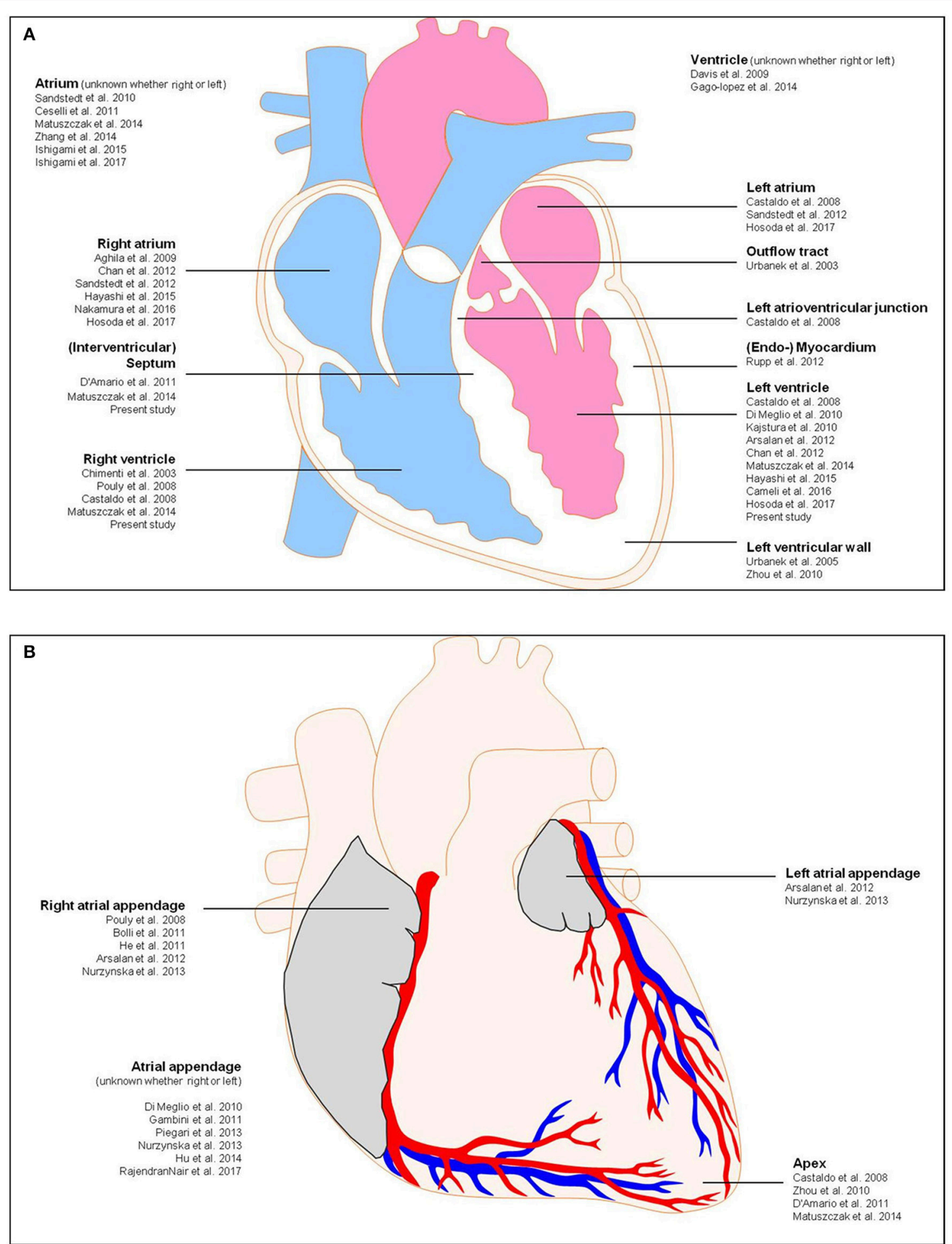

FIGURE 1 | Schematic representation of the human heart showing biopsy locations used for previous identifications of CD117 and CD90. (A) Anterior view, (B) frontal section. Detailed information about the previous studies is shown in Table 1.

of Medicine, Anatomy and Molecular Embryology). Individual image processing and optimization were performed via cellSens Software (OLYMPUS Germany). Fully automatic image analysis using the Definiens Tissue Phenomics ${ }^{\circledR}$ Technology (DEFINIENS AG, Munich, Germany) and the image analysis platform Developer XD enabled a quantitative image analysis 

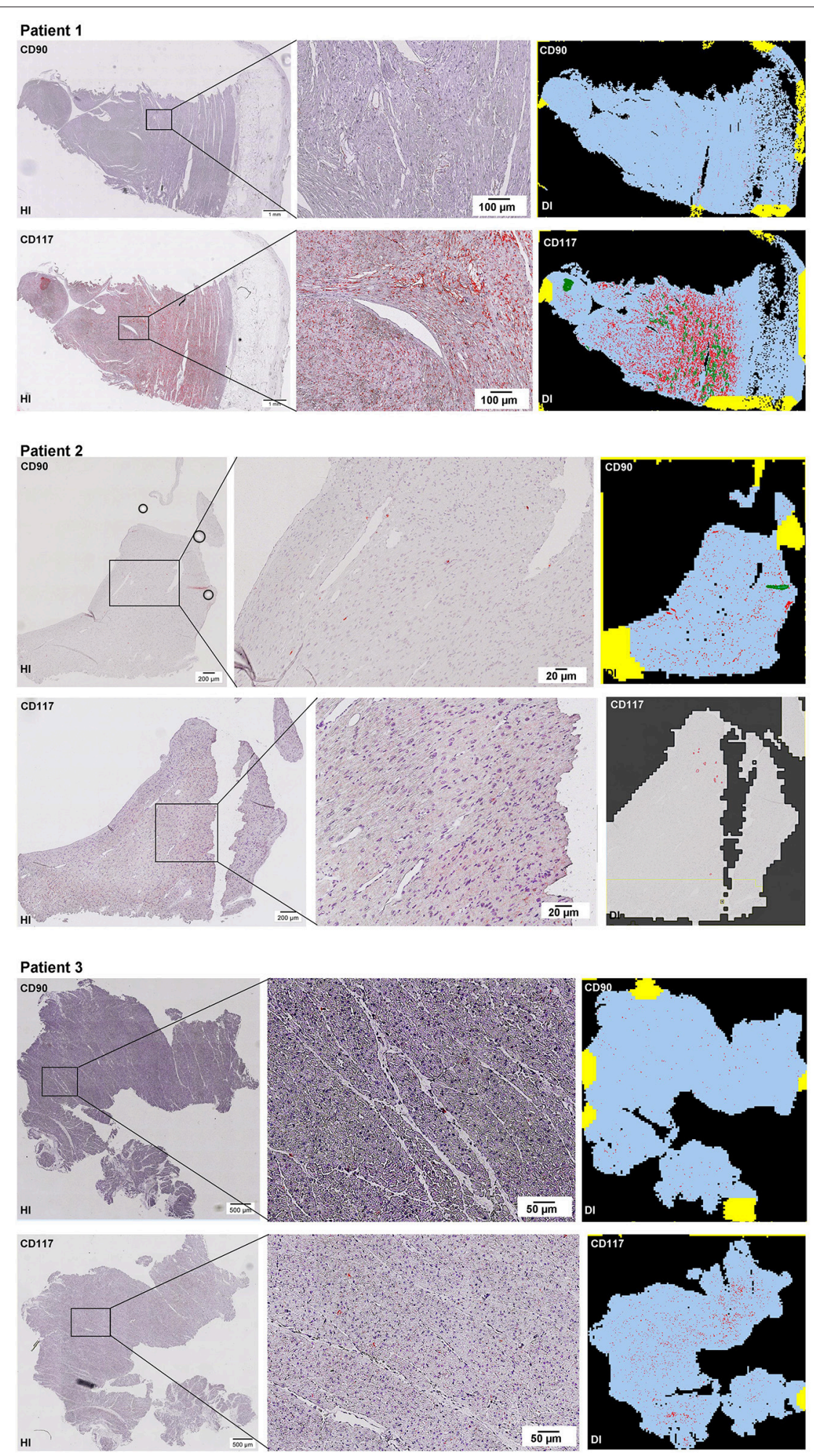

FIGURES 2-10 | Histological and digital images of all tissue sections $(n=92)$. (HI) Histological whole slide images scanned with virtual slide microscope VS120 and (DI) reprocessed images, resulting from digital image analysis using the Definiens Tissue Phenomics ${ }^{\circledR}$ Technology. (2) Healthy cardiac patients, (3) patients with Myocarditis, (4-7) patients with ICM, (8-10) patients with DCM. Full-size images are available for download (https://figshare.com/s/13e838d63dfeac772894). 

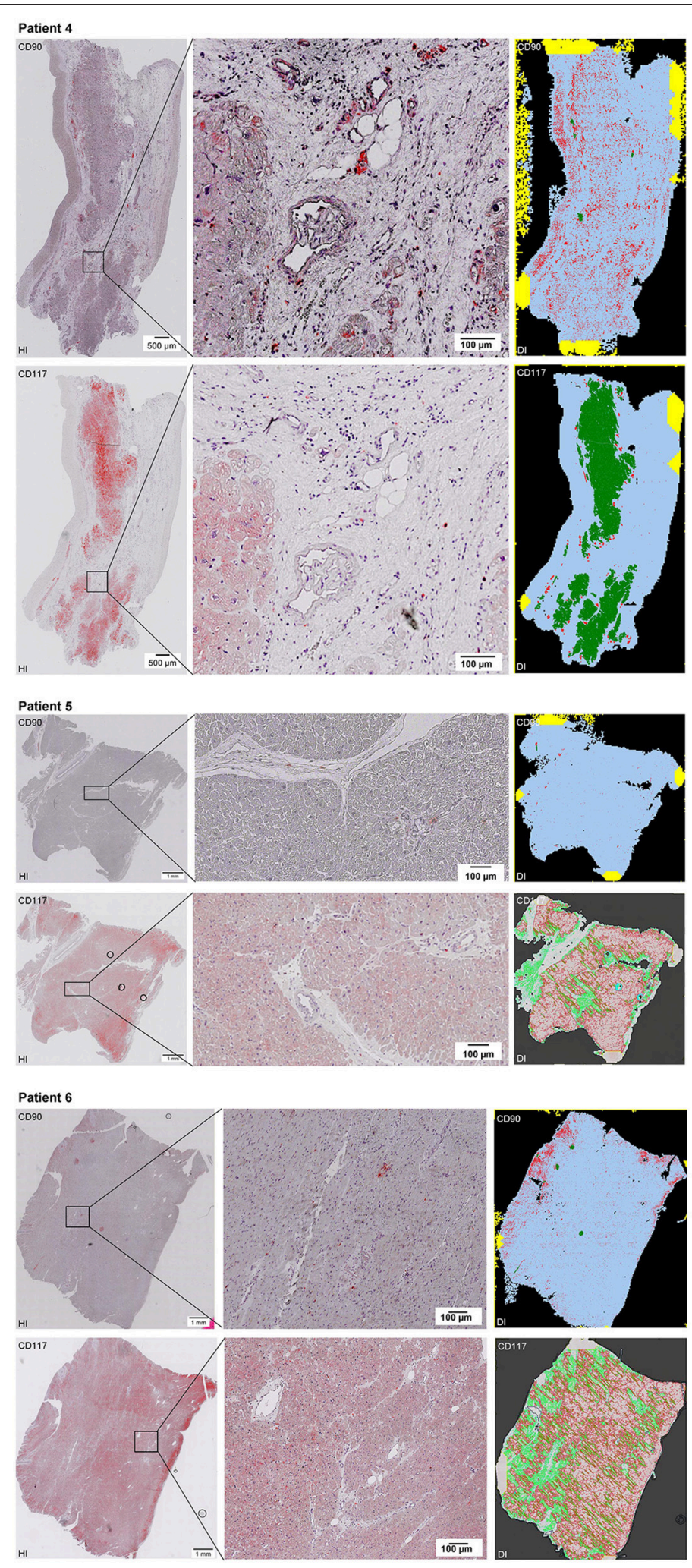

FIGURE 3 | See Figure 2. 


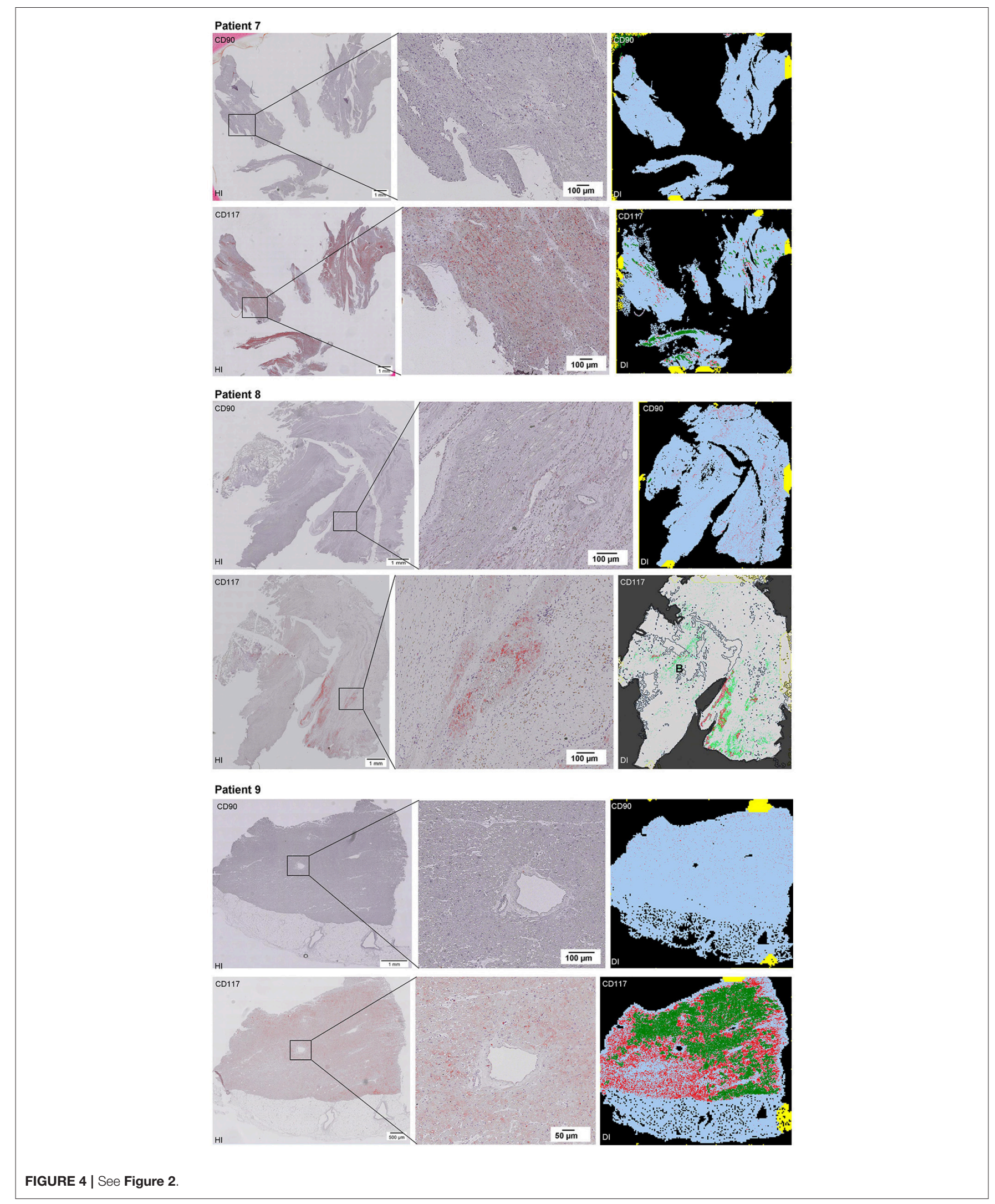




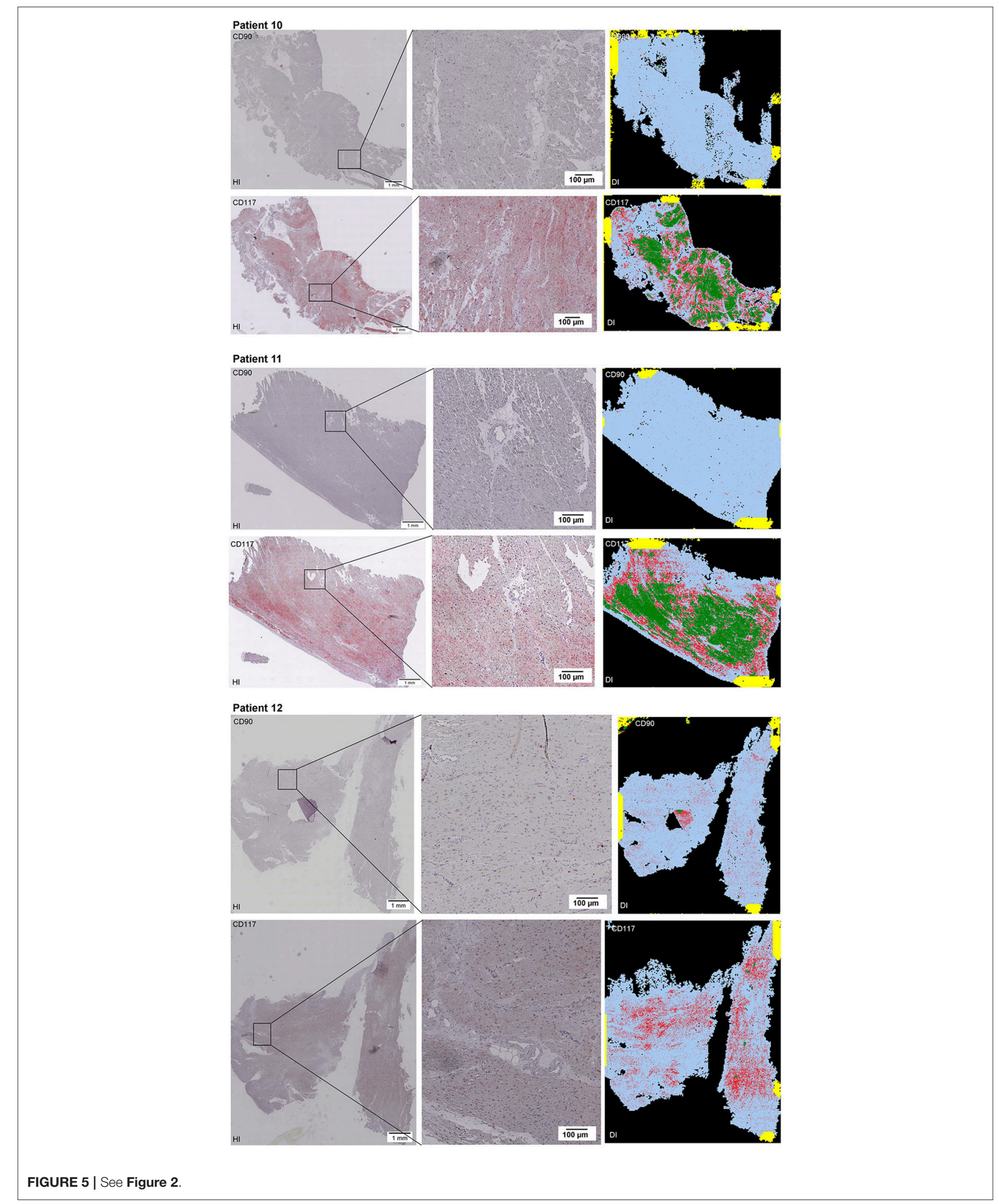



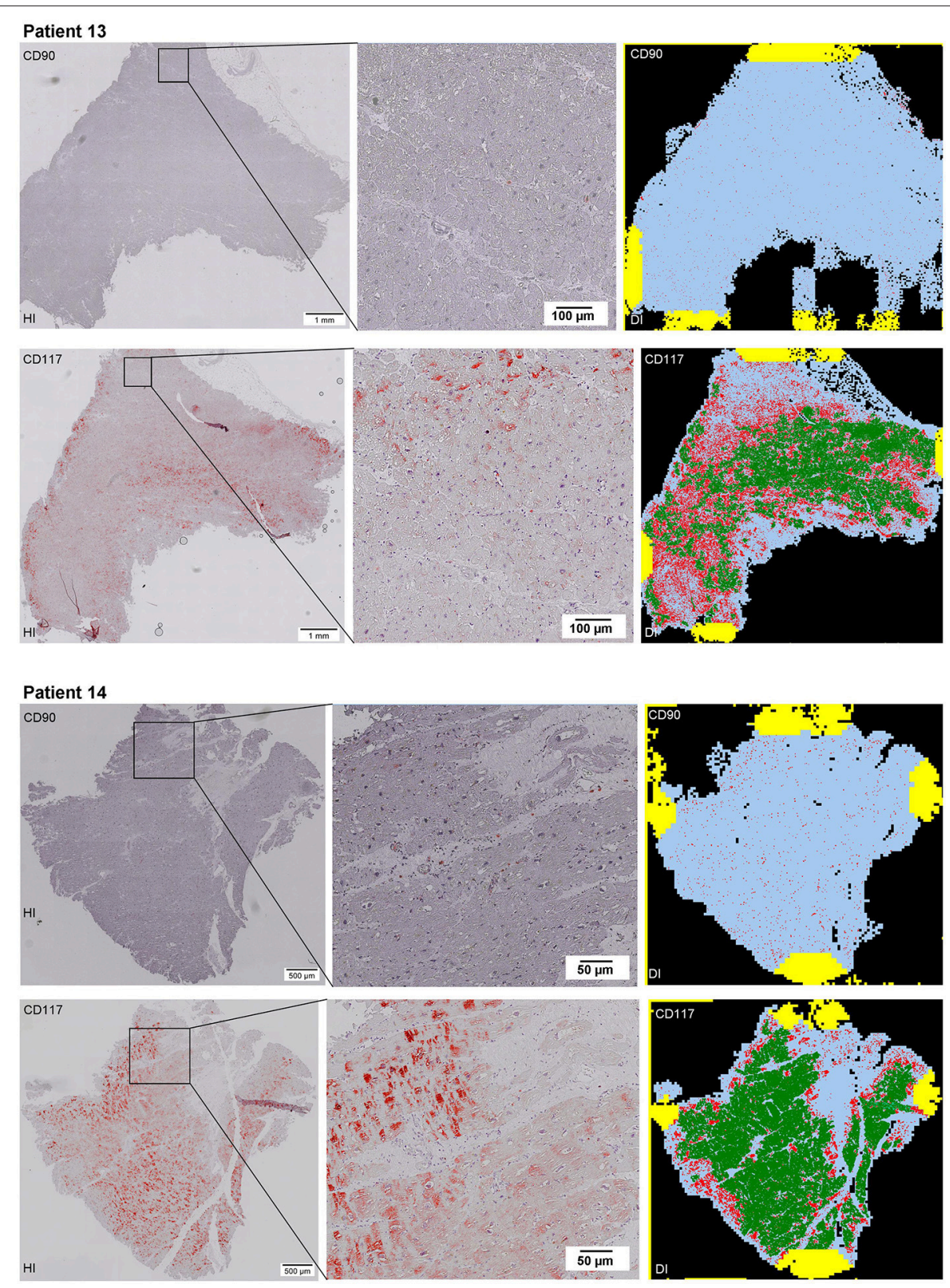

FIGURE 6 | See Figure 2

of the whole slide. The analysis was made with the original image files (*vsi), which were created by the Olympus Virtual Slide Microscope using the 20x objective and have a very high resolution until the cellular level. A tailored image analysis solution (rule set) was developed using Definiens AG Software. The rule set separated first foreground (tissue regions) from the background (image regions without tissue) and excluded tissue along the edge to avoid artifacts. In the next step, the solution segmented and classified signals according to their individual morphology and their relative staining intensity. Afterwards, the solution reclassified the signals into two groups: in single signals and concatenated signals. The relative number of $\mathrm{CD}^{+} 0^{+}$signals (total number of signals divided by the total area of tissue section), the relative area of $\mathrm{CD}^{+} 0^{+}$signals and relative area of $\mathrm{CD} 117^{+}$signals (total area of signals divided by the total area of tissue section) were calculated.

To classify the cells as local progenitor cells, the detection of several stem cell markers was necessary. As we utilized only one antibody per slide, the identification of cells with co-expression of several markers was done through visual comparison of two or rather three serial sections each. A representative field 

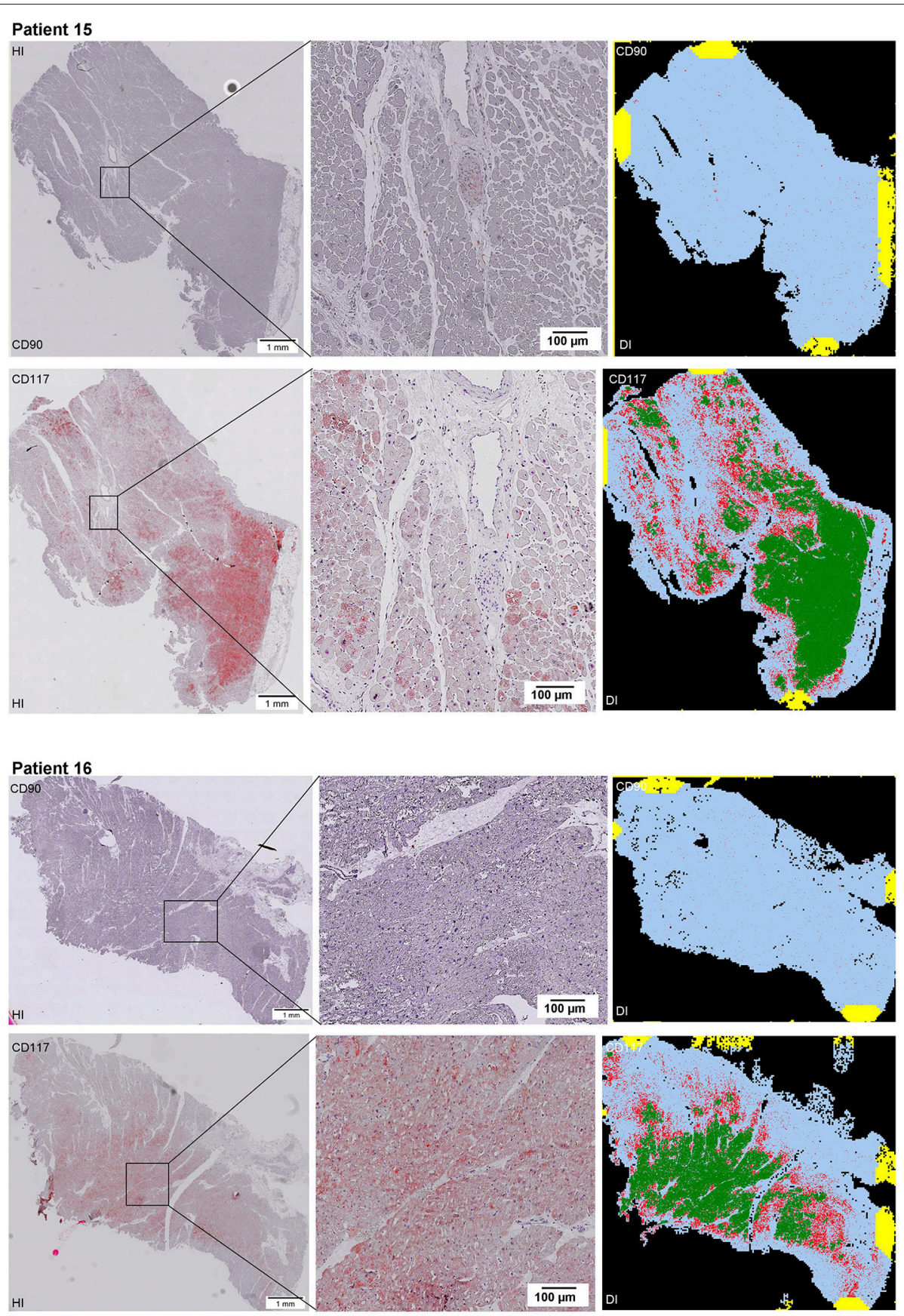

FIGURE 7 | See Figure 2.

$\left(4 \mathrm{~mm}^{2}\right)$ with high histological quality was chosen to account for the variable size of the tissue samples. The total number of cells, which expressed both stem cell markers, CD90 and CD117, was counted and normalized per square millimeter. This procedure was performed in three examples of each group; the ones that had the best histological quality were chosen.

\section{Statistics}

The data obtained from digital image analysis are best analyzed on the logit scale $[\operatorname{logit}(p)=\log (p /(1-p))]$. Analyses were performed in Microsoft Excel 2007. The statistical significance of differences between groups was evaluated by ANOVA (analysis of variance, one way), followed up by a post-hoc test (Tukey-Kramer method). $P<0.05$ was considered statistically significant. The 

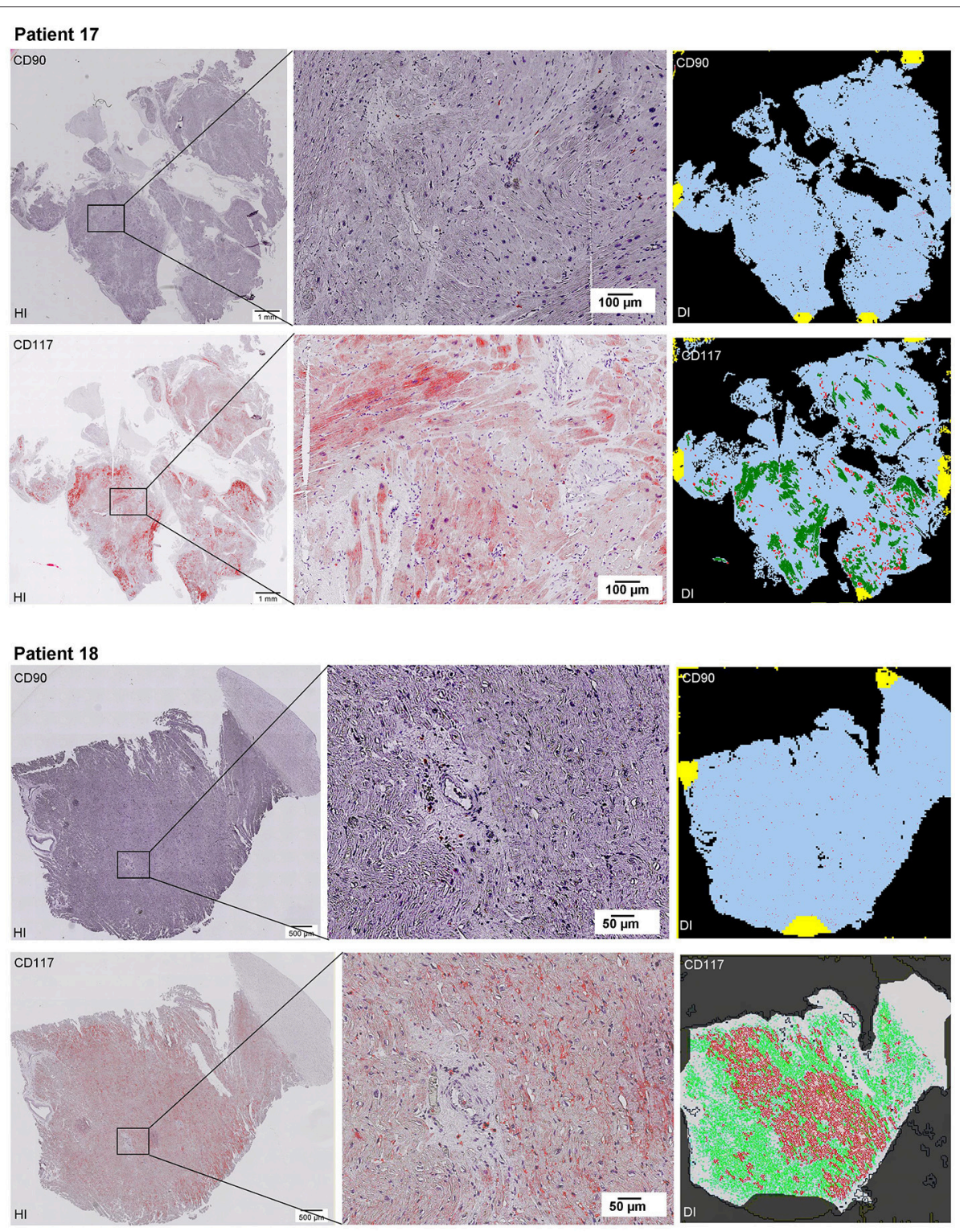

FIGURE 8 | See Figure 2

results from co-expression analysis were expressed as the mean \pm standard deviation.

\section{RESULTS}

\section{Identification of $\mathrm{CD}^{+} 0^{+}$and $\mathrm{CD} 117^{+}$Cells}

Scanning of the whole slide enabled a detailed view of the tissue sections in entirety and provided the basis for creating new images for the digital image analysis (Figures 2-10; high resolution images are available for download here: https:// figshare.com/s/13e838d63dfeac772894). The histological analysis showed positive CD90 and CD117 signals in every group. $\mathrm{CD}^{+}{ }^{+}$cells were detected as individual signals between the cardiomyocytes. In contrast, the $\mathrm{CD}_{11} 7^{+}$signals were identified both in cardiomyocytes and in cells which are located between the muscle cells. In many patients, the CD117 staining of the cardiomyocytes seems to predominate and only few signals in the interstitium were proved.

The digital image analysis facilitated a specialized quantitative analysis of the whole slide to $\mathrm{CD}^{+} 0^{+}$and $\mathrm{CD}_{117^{+}}$signals. The relative number of $\mathrm{CD}^{+} 0^{+}$signals (total number of signals divided by the total area of tissue section) and the relative area of $\mathrm{CD} 0^{+}$signals (total area of signals divided by the total area of the tissue section) were calculated (Table 2). On comparison of the acute and chronic disease states of the heart in this study, it is striking to see that the highest expression of $\mathrm{CD}^{+} 0^{+}$cells was detected in the myocarditis group (Figure 11A). ICM and DCM groups have similar numbers of $\mathrm{CD}^{+} 0^{+}$cells or even 

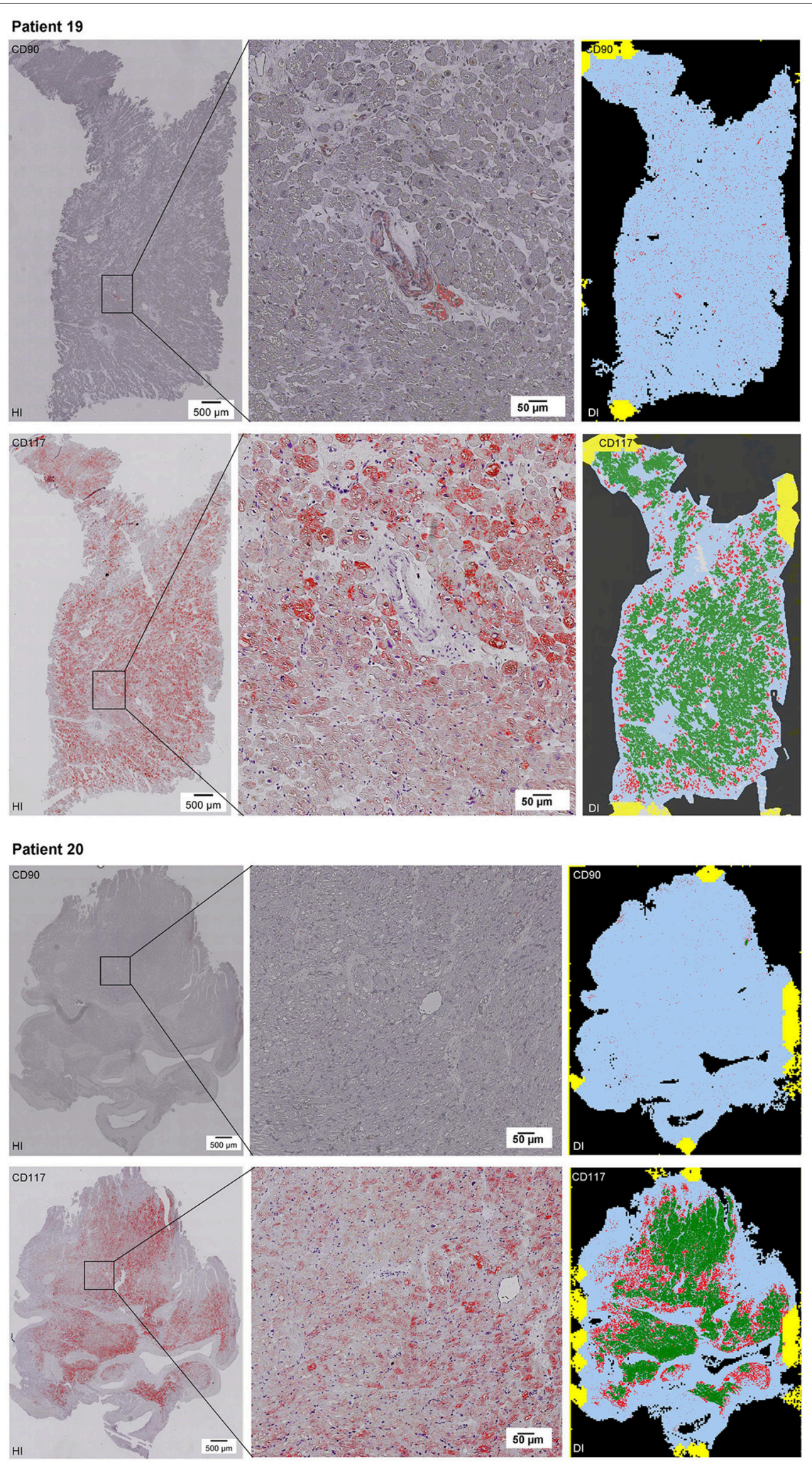

FIGURE 9 | See Figure 2. 


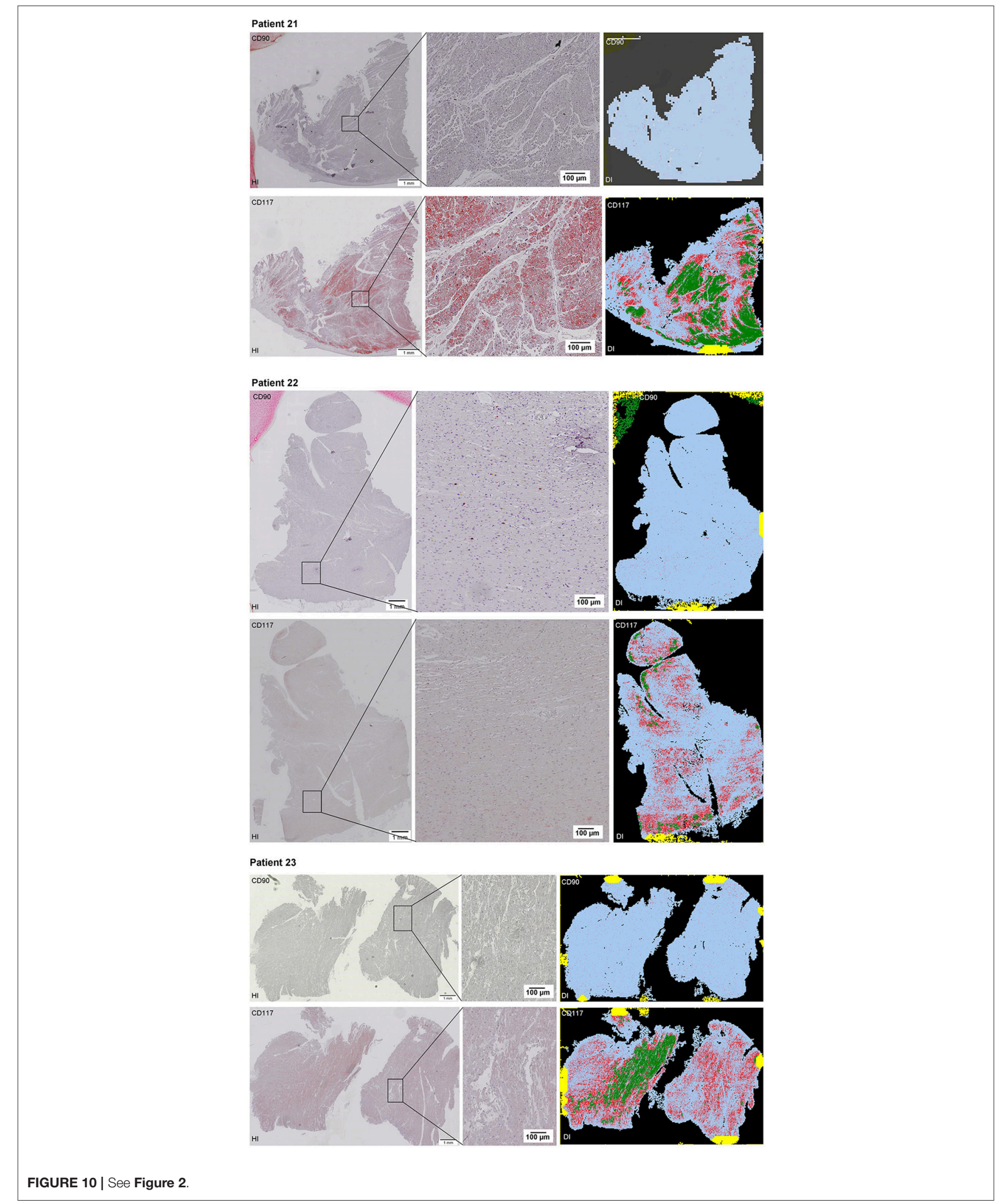


lower, in comparison to healthy cardiac patients. The relative area of CD90 (Figure 11B) correlates with the relative number of $\mathrm{CD}^{+} 0^{+}$signals. The greatest relative area of CD90 was found in the myocarditis group, even though no statistical evidence for group differences was detected.

As CD117 staining included not only individual signals but also larger stained areas, the focus was set on the relative area of $\mathrm{CD}_{11} 7^{+}$signals (total area of signals divided by the total area of the tissue section) and not on the number of $\mathrm{CD}_{117^{+}}$signals (Table 2). The relative area of $\mathrm{CD}_{117^{+}}$signals is significantly increased in all three disease states: myocarditis, ICM and DCM, compared to healthy patients $(p<0.05$; Figure 12).

\section{Co-Expression of CD90 and CD117}

The co-localized signals were evaluated and counted manually, based on the comparison of the histological images. $\mathrm{CD} 90^{+}$ cells, which were co-localized with CD117, were identified in all patient groups (Figure 13). The lowest number of cells with co-expression was found in the group of cardiac healthy $(1 \pm$ $0.43 \mathrm{CD} 0^{+} \mathrm{CD} 117^{+}$cells $\left./ \mathrm{mm}^{2}\right)$, followed by DCM group $(1.67$ \pm 0.58 cells $\left./ \mathrm{mm}^{2}\right)$ and patients with ICM $\left(4 \pm 1.89\right.$ cells $/ \mathrm{mm}^{2}$;
Figure 14). Patients with myocarditis had by far the highest number of cells with co-expression $\left(6.75 \pm 3.25\right.$ cells $\left./ \mathrm{mm}^{2}\right)$. These results also support our previous described outcome of an increase of CD90 and CD117, especially in myocarditis. The $\mathrm{CD}_{117^{+}}$signal directly in the cardiomyocytes was not detected in the CD90 stained sections. We conclude that these cells do not belong to the local progenitor cells. Furthermore, on some selected tissue samples we analyzed a third stem cell marker, CD105, and we identified cells with expression of all three stem cell markers (Figure 15).

\section{DISCUSSION}

Numerous stem cell markers were analyzed especially referring to CPCs. In the present study, the focus was mainly set on the co-expression of CD90 and CD117 in the human heart, which was already demonstrated (Gambini et al., 2011). In general, the CD90 marker is considered as a fibroblast marker but is also known as a mesenchymal stem cell (MSC) marker. Cardiac fibroblast research has been tremendously accelerated in the last decade (Gourdie et al., 2016). The novel therapeutic strategies

TABLE 2 | Detailed patient information including biopsy location, diagnosis, and results of the digital image analysis ( $n=23$ ).

\begin{tabular}{|c|c|c|c|c|c|c|}
\hline Patient ID & Biopsy location & Diagnosis & $\begin{array}{l}\text { Total number of } \\
\text { CD90+ signals per } \\
\text { tissue section }\end{array}$ & $\begin{array}{l}\text { Relative number of } \\
\text { CD90+ signals per } \\
\text { tissue section }\end{array}$ & $\begin{array}{l}\text { Relative area of } \\
\text { CD90+ signals per } \\
\text { tissue section }\end{array}$ & $\begin{array}{c}\text { Relative area of } \\
{\text { CD } 117^{+} \text {signals per }} \\
\text { tissue section }\end{array}$ \\
\hline Patient 1 & Right ventricle & Healthy & 1,766 & 0.00006964 & 0.00657148 & 0.15489015 \\
\hline Patient 2 & Ventricle & Healthy & 986 & 0.00034775 & 0.02691154 & 0.00128155 \\
\hline Patient 3 & Ventricle & Healthy & 357 & 0.00003978 & 0.00351804 & 0.02040115 \\
\hline Average & & & 1,036 & 0.00015239 & 0.012333687 & 0.058857617 \\
\hline Patient 4 & Septum & Myocarditis & 14,493 & 0.00073061 & 0.08861789 & 0.28542232 \\
\hline Patient 5 & Septum & Myocarditis & 870 & 0.00004446 & 0.00457649 & 0.60600118 \\
\hline Patient 6 & Septum & Myocarditis & 13,860 & 0.00035446 & 0.04414038 & 0.64796254 \\
\hline Average & & & 9,741 & 0.00037651 & 0.045778253 & 0.51312868 \\
\hline Patient 7 & Septum & $\mathrm{ICM}$ & 3,003 & 0.00009935 & 0.00788957 & 0.07027659 \\
\hline Patient 8 & Left ventricle & $\mathrm{ICM}$ & 7,000 & 0.00021093 & 0.01858989 & 0.01535276 \\
\hline Patient 9 & Left ventricle & $\mathrm{ICM}$ & 1,562 & 0.00008959 & 0.00703351 & 0.41275665 \\
\hline Patient 10 & Septum & ICM & 3,566 & 0.00013633 & 0.01256228 & 0.40487681 \\
\hline Patietn 11 & Septum & $\mathrm{ICM}$ & 1,230 & 0.00006138 & 0.00538673 & 0.48448345 \\
\hline Patient 12 & Septum & $\mathrm{ICM}$ & 12,254 & 0.00055332 & 0.04938569 & 0.13488475 \\
\hline Patient 13 & Left ventricle & $\mathrm{ICM}$ & 1,977 & 0.00008794 & 0.00760771 & 0.48799854 \\
\hline Patient 14 & Left ventricle & $\mathrm{ICM}$ & 1,190 & 0.0001929 & 0.01611067 & 0.57780017 \\
\hline Patient 15 & Left ventricle & $\mathrm{ICM}$ & 781 & 0.00003774 & 0.00313921 & 0.41058415 \\
\hline Patient 16 & Left ventricle & $\mathrm{ICM}$ & 793 & 0.00004349 & 0.00341586 & 0.32906417 \\
\hline Average & & & 3,336 & 0.000151297 & 0.013112112 & 0.332807804 \\
\hline Patient 17 & Left ventricle & DCM & 1,634 & 0.00005087 & 0.00423627 & 0.15127794 \\
\hline Patient 18 & Septum & DCM & 626 & 0.00004535 & 0.00356114 & 0.21075096 \\
\hline Patient 19 & Septum & DCM & 4,203 & 0.00022521 & 0.01916202 & 0.45260291 \\
\hline Patient 20 & Left ventricle & DCM & 1,388 & 0.00006808 & 0.00492588 & 0.3632407 \\
\hline Patient 21 & Septum & DCM & 96 & 0.00000503 & 0.00120728 & 0.36082968 \\
\hline Patient 22 & Left ventricle & DCM & 3,251 & 0.00008052 & 0.00644762 & 0.1610318 \\
\hline Patient 23 & Septum & DCM & 3,808 & 0.00011138 & 0.00938711 & 0.30622664 \\
\hline Average & & & 2,144 & 8.37771E-05 & 0.006989617 & 0.286565804 \\
\hline
\end{tabular}



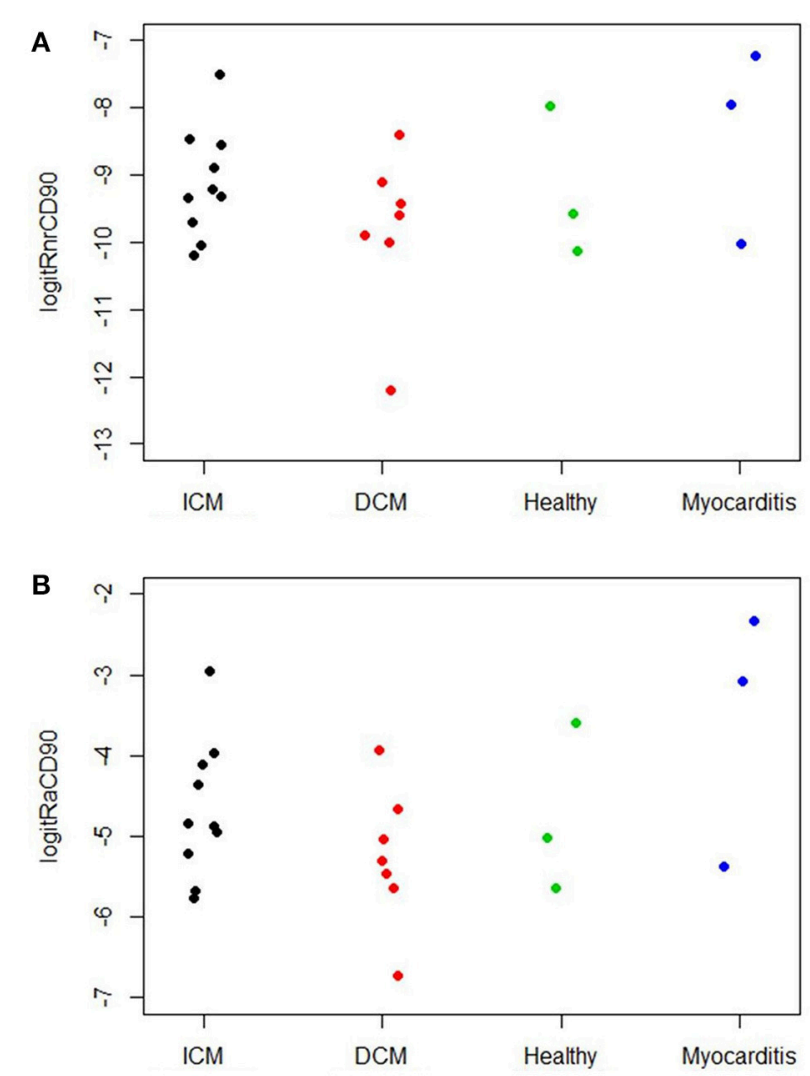

FIGURE 11 | (A) Relative number of CD90+ cells per tissue section $(n=23)$. The $X$ axis designates the patient groups: $\operatorname{ICM}(n=10), \operatorname{DCM}(n=7)$, Healthy $(n=3)$, and Myocarditis $(n=3)$. The $Y$ axis presents the relative number of $\mathrm{CD}^{+}$signals (total number of signals divided by total area of tissue section; Table 2), converted to the logit scale $[\operatorname{logit}(p)=\log (p /(1-p))]$. Individual values of the patients are presented as spots. (B) Relative area of CD90 per tissue section $(n=23)$. The $X$ axis designates the patient groups: ICM ( $n=$ $10)$, DCM $(n=7)$, Healthy $(n=3)$, and Myocarditis $(n=3)$. The $Y$ axis presents the relative area of $\mathrm{CD}^{+}{ }^{+}$signals (total area of signals divided by total area of tissue section; Table 2), converted to logit scale [logit(p) $=\log (p /(1-p))]$. Individual values are presented as spots.

in heart diseases with special focus on fibroblasts are reviewed elsewhere (Gourdie et al., 2016). In our previous studies, we have shown the multilineage potential of skin-derived $\mathrm{CD}^{+}{ }^{+}$cells (Lorenz et al., 2008). Moreover, we have successfully treated acute and chronic diabetic wounds and skin ulcer of human cases by activation of local progenitor cells (Bader et al., 2011; Günter et al., 2013). In our opinion, it is important to note that the CD90 marker characterizes seemingly opposing states of cells; on the one hand fibroblasts involved in scar formation, but on the other hand, stem or progenitor cells, which could induce functional tissue regeneration. We believe that those $\mathrm{CD} 90^{+}$ progenitor cells reside in local organs and are activated after injury. Previously, we have studied CD90 progenitor cells of the skin and shown their dependence toward localized cytokine stimulation for proliferation (Lorenz et al., 2008) and we proved the proliferation of local $\mathrm{CD}^{+} 0^{+}$progenitor cells after injury in the liver (unpublished data). Acute myocarditis is a process

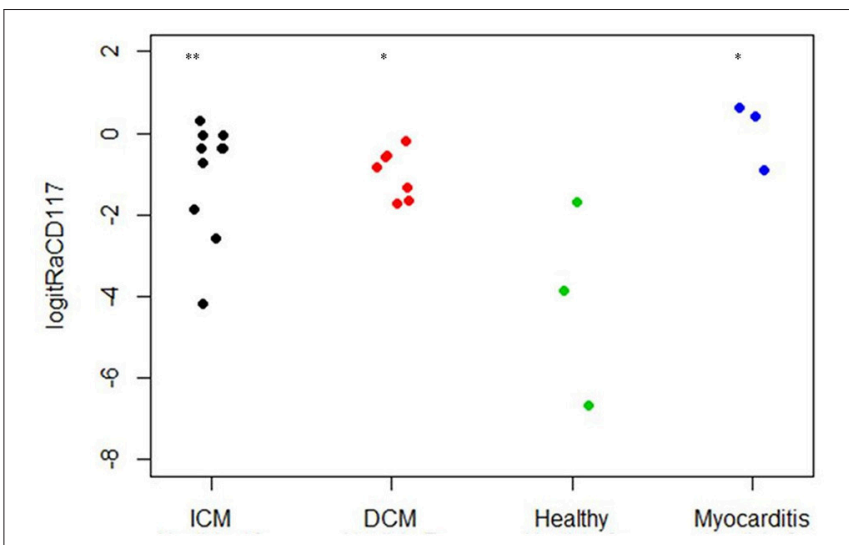

FIGURE 12 | Relative area of CD117 per tissue section $(n=23)$. The $\mathrm{X}$ axis designates the patient groups: $\operatorname{ICM}(n=10), \operatorname{DCM}(n=7)$, Healthy $(n=3)$, and Myocarditis $(n=3)$. The $Y$ axis presents the relative area of $C D 117^{+}$signals (total area of signals divided by total area of tissue section; Table 2), converted to logit scale $[\log i t(p)=\log (p /(1-p))]$. Individual values are presented as spots. The expression of CD117 is significantly higher in ICM, DCM and Myocarditis, compared to healthy $\left({ }^{\star} P<0.05\right.$ vs. healthy, ${ }^{* \star} P<0.01$ vs. healthy).

that is characterized by intense local inflammation as well. Even though the myocarditis group in the present experiments was very small $(n=3)$ due to the limited availability of the samples, the high expression of $\mathrm{CD}^{+} 0^{+}$cells corresponds to the fact that myocarditis patients more frequently undergo a complete healing pattern. The progenitor cell activation in myocarditis may explain the better functional outcome with less or no scar presence allowing the localized functional regeneration of cardiac tissue. In contrast, chronic disease states showed a depletion of $\mathrm{CD}^{+} 0^{+}$cells, correlating clinically to the unsuccessful healing outcomes.

Moreover, various researchers identified $\mathrm{CD}_{11}{ }^{+}$cells in human myometrium (Ciontea et al., 2005), human fallopian tube (Popescu et al., 2005), human mammary gland stroma (Radu et al., 2005) as well as in human atrial myocardium (Hinescu et al., 2006), and ventricular myocardium (Popescu et al., 2006). We have proved here, that the number of $\mathrm{CD}_{11} 7^{+}$cells is upregulated in the diseased heart, especially in myocarditis. Our results validate the findings of previous studies; the number of $\mathrm{CD}_{117^{+}}$cells is increased in several cardiac diseases, for instance in advanced heart failure and aortic stenosis (Urbanek et al., 2003; Kubo et al., 2008; Itzhaki-Alfia et al., 2009). The human heart possesses a cardiac stem cell pool (Urbanek et al., 2005). The activation of the local stem cells occurs in response to ischemic injury. The stem cell pool has a crucial role in the regeneration of infarction heart (Urbanek et al., 2005). Matuszczak et al. reported that there are no differences in the number of $\mathrm{CD} 117^{+}$ cells between various disease groups (Matuszczak et al., 2014). However, they had not used control tissue from healthy patients.

$\mathrm{CD} 117^{+}$local CPCs had already been used for the treatment of heart diseases in both human cases and animal models (Bolli et al., 2011). The method involves the isolation of autologous $\mathrm{CD}_{117^{+}}$cells, expansion in vitro and injection of those in high numbers (Bolli et al., 2011). 

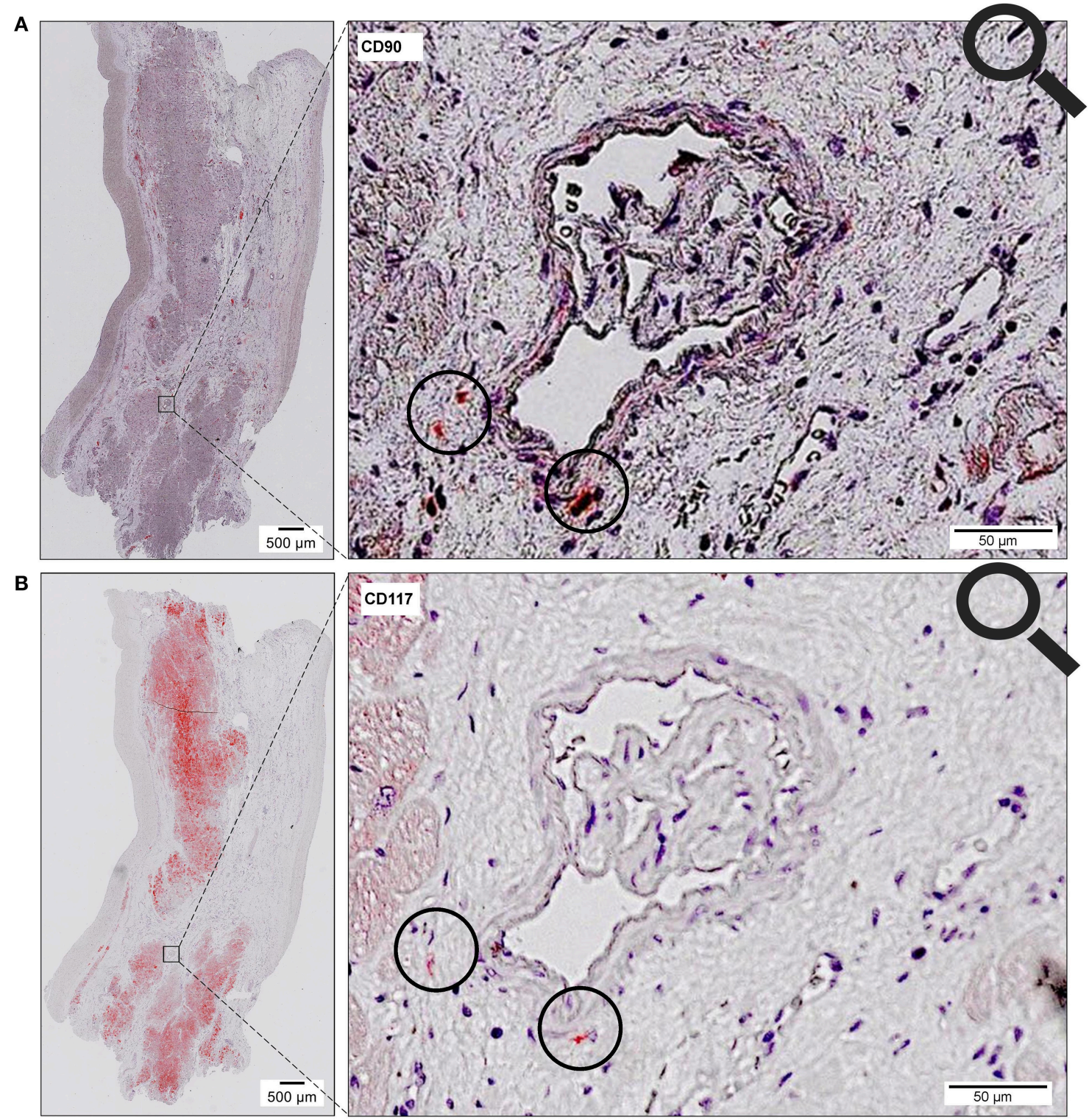

FIGURE 13 | Coexpression of CD90 and CD117. Two serial sections of the same patient (Patient 4) are stained with different antibodies (A, CD90; B, CD117). The circle shows cells with co-expression of both stem cell markers (CD90 ${ }^{+}$on 1 st slide, $\mathrm{CD} 117^{+}$on 2nd slide).

In comparison with conventional stem cell therapy, the activation of local endogenous progenitor cells is a holistic approach to both preventing and regulating the heart. We are aware that the characterization of progenitor cells requires the identification of various stem cell markers and it is of high importance to exclude unspecific signals. Here, we analyzed the co-expression of CD117, CD90, and partially CD105, also. Previous studies underline our analyses: Gambini and colleagues demonstrated a co-expression of CD117 and CD90 or rather CD105 in human heart auricle primary cultured cells (Gambini et al., 2011). Several other studies also identified CD117 ${ }^{+}$cells which were positive for CD105 and CD90, too (Li et al., 2012;
Matuszczak et al., 2014). CD90 and CD105 were detected on cardiosphere-derived cells (CDCs) (Smith et al., 2007; Davis et al., 2009; Mishra et al., 2011; Chan et al., 2012). A series of other markers was proven on $\mathrm{CD}_{11}{ }^{+}$cells, including CD29, CD44, CD31, CD34, and Sca1 (Gambini et al., 2011; Fang et al., 2012; Matuszczak et al., 2014). Furthermore, it was already displayed that CD117+ cardiac stem cells are negative for CD45 (Matuszczak et al., 2014) and that not all CD117 ${ }^{+}$cells are mast cells (Kubo et al., 2008; Zhou et al., 2010).

Vicinanza et al. also showed that cardiac $\mathrm{CD} 117^{+} / \mathrm{CD} 45^{-}$ cells are clonogenic and multipotent, but they determined that $>90 \%$ of cardiac $\mathrm{CD} 117^{+}$cells contain endothelial cells and 
their precursors (Vicinanza et al., 2017). They demonstrated the myogenic and regenerative potential of $\mathrm{CD} 117^{+} / \mathrm{CD} 45^{-}$cells in the damaged myocardium after injection of $\mathrm{CD} 117^{+} / \mathrm{CD} 45^{-}$ cells into damaged myocardium. Therefore, they conclude that CD117 is still an essential marker for CPCs (Vicinanza et al., 2017).

Nevertheless, future experiments with additional stem cell markers are necessary to prove the progenitor cell identity of $\mathrm{CD}_{117^{+}}$cardiac cells and to exclude unspecific labeling. We identified many $\mathrm{CD}_{11}{ }^{+}$stained cardiomyocytes, which do not belong to the local progenitor cells. Other researchers studied $\mathrm{CD}_{1} 7^{+}$hematopoietic bone marrow cells and their ability to act as cardiac progenitors and to transdifferentiate into cardiomyocytes (Orlic et al., 2001; Rota et al., 2007). Rota et al. reported that $\mathrm{CD}_{11} 7^{+}$bone marrow cells lose their hematopoietic CD45 phenotype and obtain a cardiomyocyte phenotype (Rota et al., 2007). Probably these cells were also enriched in cases of inflammation or other pathological conditions. Further studies would be necessary to analyze this kind of cells.

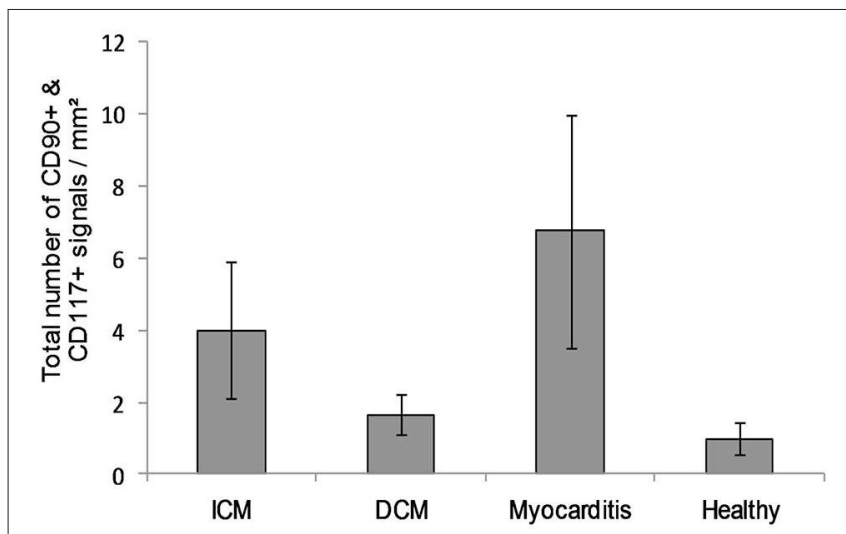

FIGURE 14 | A number of cells with co-expression of CD90 and CD117 per square millimeter $(n=12)$. The data are expressed as mean \pm standard deviation. The Myocarditis patient group displayed the most cells with co-expression of both stem cell markers.
In the present study, it was not our purpose to perform a series analysis of cardiac stem cell markers. Rather than that, the present study mainly focuses on investigating the combination of a traditional histological method with a novel digital image analysis technology. This technology enables a quantitative evaluation of two CPC markers in comparison of paraffin-embedded tissue sections of healthy and diseases heart samples. It would be of high interest to complement these experiments with other techniques such as immunofluorescence and high magnification confocal microscopy in the future.

In the present experiment, we identified $\mathrm{CD}^{+} 0^{+}$and $\mathrm{CD}_{117^{+}}$cells in all patient groups: Myocarditis, ICM, DCM, and healthy cardiac patients. With the novel digital image analysis technology, a comparison of differently sized paraffinembedded tissue sections is available. Taking into consideration that the sample size in the present experiment was limited, we proved an increase of $\mathrm{CD}^{+} 0^{+} / \mathrm{CD} 117^{+}$cells in acute myocarditis. This finding supports our theory that endogenous cardiac stem or progenitor cell activation is part of the repairing mechanism after acute myocardial damage, as in cases of acute myocarditis. A similar inflammation process is described for acute myocardial infarction. Nevertheless, in most cases, acute myocardial infarction leads to the development of a scar. Further studies may show, how an amplification of the local myocardial stem or progenitor cell activation may contribute to the myocardial regeneration and healing process.

\section{CONCLUSION}

This study aimed at the identification and the quantitative analysis of $\mathrm{CD}^{+}$and $\mathrm{CD}^{+} 17^{+}$cardiac cells from human myocardium biopsies of 23 patients. Besides the conventional histological image analysis, the digital image analysis enabled a computer-based immunohistochemical quantification of some stem cell markers, using whole-slide images created by the virtual slide scanning microscopy. In our experiments, the number of CD90 and CD117 signals in patients with myocarditis was higher than in all other groups. Taking into consideration

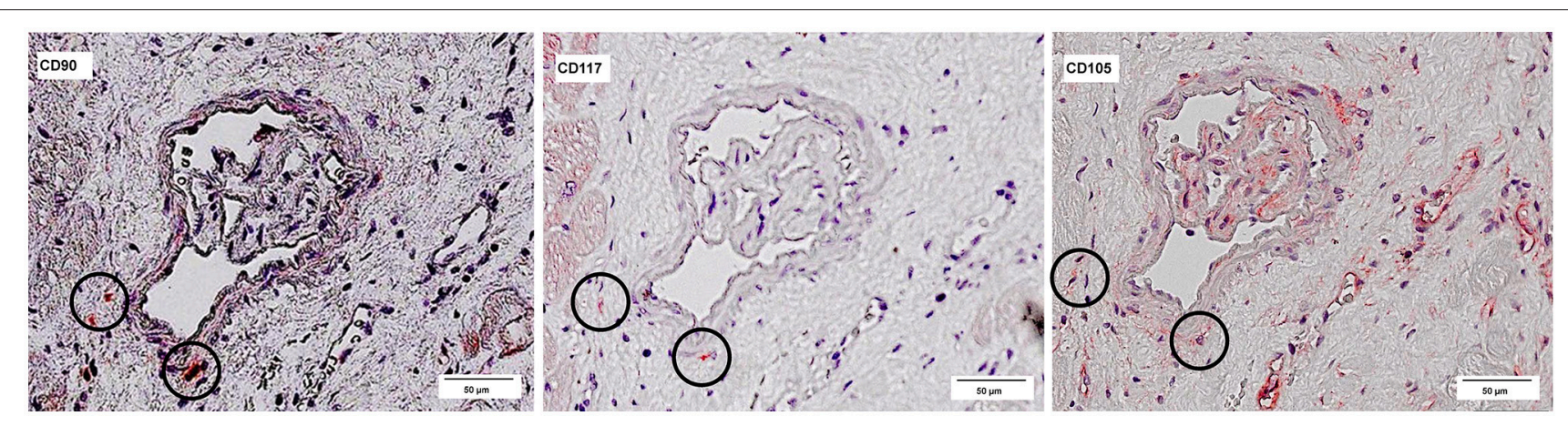

FIGURE 15 | Co-expression of CD90, CD117, and CD105. Three serial sections of the same patient (Patient 4) are stained with different antibodies: CD90, CD117, and CD105. The circles mark cells, which are positive for all three antibodies. 
the regenerative healing potential prospects of myocarditis, it is likely that there is a relation between CD90 and CD117 expression and clinical outcome. Future studies with larger sample size are necessary to confirm that theory. The proof on the existence of endogenous resident progenitor cells not only in the healthy but also in the diseased human heart opens up the promising concept of regeneration instead of repair, which has an impressive scope in treating or preventing cardiovascular diseases.

\section{AUTHOR CONTRIBUTIONS}

MG, JS, SE, SG, and AB: conceived and designed the experiments; NS, WM, and JS: organized the human tissue samples; MG and SE: performed the experiments; MG, SE, BB-S, and MA: analyzed the data; MG, JS, SE, SG, AB, and MA: wrote the paper; $S G$ and $A B$ : provided guidance on the whole study.

\section{REFERENCES}

Abraham, B. K., Fritz, P., McClellan, M., Hauptvogel, P., Athelogou, M., and Brauch, H. (2005). Prevalence of $\mathrm{CD} 44^{+} / \mathrm{CD} 24^{-/ \text {low }}$ cells in breast cancer may not be associated with clinical outcome but may favor distant metastasis. Clin. Cancer Res. 11, 1154-1159. Available online at: http://clincancerres. aacrjournals.org/content/11/3/1154.long

Aghila Rani, K. G., Jayakumar, K., Sarma, P. S., and Kartha, C. C. (2009). Clinical determinants of ckit-positive cardiac cell yield in coronary disease. Asian Cardiovasc. Thorac. Ann. 17, 139-142. doi: 10.1177/0218492309103292

Altarche-Xifró, W., Curato, C., Kaschina, E., Grzesiak, A., Slavic, S., Dong, J., et al. (2009). Cardiac c-kit+AT2 + cell population is increased in response to ischemic injury and supports cardiomyocyte performance. Stem Cells 27, 2488-2497. doi: 10.1002/stem.171

Anversa, P., Kajstura, J., Leri, A., and Bolli, R. (2006). Life and death of cardiac stem cells: a paradigm shift in cardiac biology. Circulation 113, 1451-1463. doi: 10.1161/CIRCULATIONAHA.105.595181

Arsalan, M., Woitek, F., Adams, V., Linke, A., Barten, M. J., Dhein, S., et al. (2012). Distribution of cardiac stem cells in the human heart. ISRN Cardiol. 2012:483407. doi: 10.5402/2012/483407

Bader, A., Lorenz, K., Richter, A., Scheffler, K., Kern, L., Ebert, S., et al. (2011). Interactive role of trauma cytokines and erythropoietin and their therapeutic potential for acute and chronic wounds. Rejuvenation Res. 14, 57-66. doi: 10.1089/rej.2010.1050

Bearzi, C., Rota, M., Hosoda, T., Tillmanns, J., Nascimbene, A., and De Angelis, A., et al. (2007). Human cardiac stem cells. Proc. Natl. Acad. Sci. U.S.A. 104, 14068-14073. doi: 10.1073/pnas.0706760104

Beltrami, A. P., Barlucchi, L., Torella, D., Baker, M., Limana, F., Chimenti, S., et al. (2003). Adult cardiac stem cells are multipotent and support myocardial regeneration. Cell 114, 763-776. doi: 10.1016/S0092-8674(03)00687-1

Beltrami, A. P., Urbanek, K., Kajstura, J., Yan, S. M., Finato, N., Bussani, R., et al. (2001). Evidence that human cardiac myocytes divide after myocardial infarction. N. Engl. J. Med. 344, 1750-1757. doi: 10.1056/NEJM200106073442303

Bolli, R., Chugh, A. R., D’Amario, D., Loughran, J. H., Stoddard, M. F., Ikram, S., et al. (2011). Cardiac stem cells in patients with ischaemic cardiomyopathy (SCIPIO): initial results of a randomised phase 1 trial. Lancet 378, 1847-1857. doi: 10.1016/S0140-6736(11)61590-0

Cameli, M., Righini, F. M., Sparla, S., Tacchini, D., Dokollari, A., Sassi, C. G., et al. (2016). First evidence of cardiac stem cells from the left ventricular apical tip in patients with left ventricular assist device implantation. Transplant. Proc. 48, 395-398. doi: 10.1016/j.transproceed.2015.12.045

\section{FUNDING}

The study is funded by University of Leipzig, Germany.

\section{ACKNOWLEDGMENTS}

Special thanks are extended to Prof. Dr. med. K. Klingel (Department of Molecular Pathology, University of Tuebingen, Germany) for providing the human endomyocardial biopsies and Prof. Dr. med. Christian Wittekind (Institute of Pathology, University of Leipzig, Germany) for providing human kidney tissue.

\section{SUPPLEMENTARY MATERIAL}

The Supplementary Material for this article can be found online at: https://www.frontiersin.org/articles/10.3389/fgene. 2018.00072/full\#supplementary-material

Castaldo, C., Di Meglio, F., Nurzynska, D., Romano, G., Maiello, C., Bancone, C., et al. (2008). CD117-positive cells in adult human heart are localized in the subepicardium, and their activation is associated with laminin-1 and alpha6 integrin expression. Stem Cells 26, 1723-1731. doi: 10.1634/stemcells.2007-0732

Cesselli, D., Beltrami, A. P., D’Aurizio, F., Marcon, P., Bergamin, N., Toffoletto, B., et al. (2011). Effects of age and heart failure on human cardiac stem cell function. Am. J. Pathol. 179, 349-366. doi: 10.1016/j.ajpath.2011.03.036

Chan, H H., Meher Homji, Z., Gomes, R. S., Sweeney, D., Thomas, G. N., Tan, J. J., et al. (2012). Human cardiosphere-derived cells from patients with chronic ischaemic heart disease can be routinely expanded from atrial but not epicardial ventricular biopsies. J. Cardiovasc. Trans. Res. 5, 678-687. doi: 10.1007/s12265-012-9389-0

Chimenti, C., Kajstura, J., Torella, D., Urbanek, K., Heleniak, H., Colussi, C., et al. (2003). Senescence and death of primitive cells and myocytes lead to premature cardiac aging and heart failure. Circ. Res. 93, 604-613. doi: 10.1161/01.RES.0000093985.76901.AF

Ciontea, S. M., Radu, E., Regalia, T., Ceafalan, L., Cretoiu, D., Gherghiceanu, M., et al. (2005). C-kit immunopositive interstitial cells (Cajal-type) in human myometrium. J. Cell. Mol. Med. 9, 407-420. doi: 10.1111/j.1582-4934.2005.tb00366.x

D’Amario, D., Fiorini, C., Campbell, P. M., Goichberg, P., Sanada, F., Zheng, H., et al. (2011). Functionally competent cardiac stem cells can be isolated from endomyocardial biopsies of patients with advanced cardiomyopathies. Circ. Res. 108, 857-861. doi: 10.1161/CIRCRESAHA.111.241380

Davis, D. R., Zhang, Y., Smith, R. R., Cheng, K., Terrovitis, J., Malliaras, K., et al. (2009). Validation of the cardiosphere method to culture cardiac progenitor cells from myocardial tissue. PLoS ONE 4:e7195. doi: 10.1371/journal.pone.0007195

Di Meglio, F., Castaldo, C., Nurzynska, D., Miraglia, R., Romano, V., Russolillo, V., et al. (2010). Localization and origin of cardiac CD117-positive cells: identification of a population of epicardially-derived cells in adult human heart. Ital. J. Anat. Embryol. 115, 71-78.

Fang, S., Wei, J., Pentinmikko, N., Leinonen, H., Salven, P., and Goodell, M. A. (2012). Generation of functional blood vessels from a single c-kit+ adult vascular endothelial stem cell. PLoS Biol. 10:e1001407. doi: 10.1371/journal.pbio.1001407

Gago-Lopez, N., Awaji, O., Zhang, Y., Ko, C., Nsair, A., Liem, D., et al. (2014). THY-1 receptor expression differentiates cardiosphere-derived cells with divergent cardiogenic differentiation potential. Stem Cell Rep. 2, 576-591. doi: 10.1016/j.stemcr.2014. 03.003 
Gambini, E., Pompilio, G., Biondi, A., Alamanni, F., Capogrossi, M. C., Agrifoglio, M., et al. (2011). C-kit+ cardiac progenitors exhibit mesenchymal markers and preferential cardiovascular commitment. Cardiovasc. Res. 89, 362-373. doi: $10.1093 / \mathrm{cvr} / \mathrm{cvq} 292$

Gonzalez, A., Rota, M., Nurzynska, D., Misao, Y., Tillmanns, J., Ojaimi, C., et al. (2008). Activation of cardiac progenitor cells reverses the failing heart senescent phenotype and prolongs lifespan. Circ. Res. 102, 597-606. doi: 10.1161/CIRCRESAHA.107.165464

Gourdie, R. G., Dimmeler, S., and Kohl, P. (2016). Novel therapeutic strategies targeting fibroblasts and fibrosis in heart disease. Nat. Rev. Drug Discov. 15, 620-638. doi: 10.1038/nrd.2016.89

Günter, C. I., Bader, A., Dornseifer, U., Egert, S., Dunda, S., Grieb, G., et al. (2013). A multi-center study on the regenerative effects of erythropoietin in burn and scalding injuries: study protocol for a randomized controlled trial. Trials 14:124. doi: 10.1186/1468-6708-14-124

Hayashi, E. (2015). The characterization of cardiac stem cells obtained from patients who have received left ventriculoplasty. Stem Cell Transl. Invest. 2:e537. doi: $10.14800 /$ scti.537

He, J. Q., Vu, D. M., Hunt, G., Chugh, A., Bhatnagar, A., and Bolli, R. (2011). Human cardiac stem cells isolated from atrial appendages stably express c-kit. PLoS ONE 6:e27719. doi: 10.1371/journal.pone.0027719

Hinescu, M. E., Gherghiceanu, M., Mandache, E., Ciontea, S. M., and Popescu, L. M. (2006). Interstitial Cajal-like cells (ICLC) in atrial myocardium: ultrastructural and immunohistochemical characterization. J. Cell. Mol. Med. 10, 243-257. doi: 10.1111/j.1582-4934.2006.tb00306.x

Hosoda, T., Iguchi, N., Cho, Y., Inoue, M., Murakami, T., Tabata, M., et al. (2017). The proliferative potential of human cardiac stem cells was unaffected after a long-term cryopreservation of tissue blocks. Ann. Transl. Med. 5:41. doi: $10.21037 / \mathrm{atm} .2017 .01 .69$

Hu, S., Yan, G., He, W., Liu, Z., Xu, H., and Ma, G. (2014). The influence of disease and age on human cardiac stem cells. Ann. Clin. Biochem. 51, 582-590. doi: $10.1177 / 0004563213511065$

Ishigami, S., Ohtsuki, S., Eitoku, T., Ousaka, D., Kondo, M., Kurita, Y., et al. (2017). Intracoronary cardiac progenitor cells in single ventricle physiology: the perseus (Cardiac Progenitor Cell Infusion to Treat Univentricular Heart Disease) randomized phase 2 trial. Circ. Res. 120, 1162-1173. doi: 10.1161/CIRCRESAHA.116.310253

Ishigami, S., Ohtsuki, S., Tarui, S., Ousaka, D., Eitoku, T., Kondo, M., et al. (2015). Intracoronary autologous cardiac progenitor cell transfer in patients with hypoplastic left heart syndrome: the TICAP prospective phase 1 controlled trial. Circ. Res. 116, 653-664. doi: 10.1161/CIRCRESAHA.116.304671

Itzhaki-Alfia, A., Leor, J., Raanani, E., Sternik, L., Spiegelstein, D., Netser, S., et al. (2009). Patient characteristics and cell source determine the number of isolated human cardiac progenitor cells. Circulation 120, 2559-2566. doi: 10.1161/CIRCULATIONAHA.109.849588

Kaemmerer, D., Athelogou, M., Lupp, A., Lenhardt, I., Schulz, S., Luisa, P., et al. (2014). Somatostatin receptor immunohistochemistry in neuroendocrine tumors: comparison between manual and automated evaluation. Int. J. Clin. Exp. Pathol. 7, 4971-4980.

Kajstura, J., Gurusamy, N., Ogorek, B., Goichberg, P., Clavo-Rondon, C., Hosoda, T., et al. (2010). Myocyte turnover in the aging human heart. Circ. Res. 107, 1374-1386. doi: 10.1161/CIRCRESAHA.110.231498

Kubo, H., Jaleel, N., Kumarapeli, A., Berretta, R. M., Bratinov, G., Shan, X., et al. (2008). Increased cardiac myocyte progenitors in failing human hearts. Circulation 118, 649-657. doi: 10.1161/CIRCULATIONAHA.107.761031

Li, T. S., Cheng, K., Malliaras, K., Smith, R. R., Zhang, Y., Sun, B., et al. (2012). Direct comparison of different stem cell types and subpopulations reveals superior paracrine potency and myocardial repair efficacy with cardiospherederived cells. J. Am. Coll. Cardiol. 59, 942-953. doi: 10.1016/j.jacc.2011.11.029

Lorenz, K., Sicker, M., Schmelzer, E., Rupf, T., Salvetter, J., SchulzSiegmund, M., et al. (2008). Multilineage differentiation potential of human dermal skin-derived fibroblasts. Exp. Dermatol. 17, 925-932. doi: 10.1111/j.1600-0625.2008.00724.x

Lozano, R., Naghavi, M., Foreman, K., Lim, S., Shibuya, K., Aboyans, V., et al. (2012). Global and regional mortality from 235 causes of death for 20 age groups in 1990 and 2010: a systematic analysis for the global burden of disease study 2010. Lancet 380, 2095-2128. doi: 10.1016/S0140-6736(12)61728-0
Matuszczak, S., Czapla, J., Jarosz-Biej, M., Wiśniewska, E., Cichon, T., Smolarczyk, R., et al. (2014). Characteristic of c-Kit+ progenitor cells in explanted human hearts. Clin. Res. Cardiol. 103, 711-718. doi: 10.1007/s00392-0140705-3

Mishra, R., Vijayan, K., Colletti, E. J., Harrington, D. A., Matthiesen, T. S., Simpson, D., et al. (2011). Characterization and functionality of cardiac progenitor cells in congenital heart patients. Circulation 123, 364-373. doi: 10.1161/CIRCULATIONAHA.110.971622

Nakamura, T., Hosoyama, T., Kawamura, D., Takeuchi, Y., Tanaka, Y., Samura, M., et al. (2016). Influence of aging on the quantity and quality of human cardiac stem cells. Sci. Rep. 6:22781. doi: 10.1038/srep22781

Neubauer, E., Wirtz, R. M., Kaemmerer, D., Athelogou, M., Schmidt, L., Sänger, J., et al. (2016). Comparative evaluation of three proliferation markers, Ki-67, TOP2A, and RacGAP1, in bronchopulmonary neuroendocrine neoplasms: issues and prospects. Oncotarget 7, 41959-41973. doi: 10.18632 /oncotarget. 9747

Nurzynska, D., Di Meglio, F., Romano, V., Miraglia, R., Sacco, A. M., Latino, F., et al. (2013). Cardiac primitive cells become committed to a cardiac fate in adult human heart with chronic ischemic disease but fail to acquire mature phenotype: genetic and phenotypic study. Basic Res. Cardiol. 108:320. doi: 10.1007/s00395-012-0320-2

Orlic, D., Kajstura, J., Chimenti, S., Jakoniuk, I., Anderson, S. M., Li, B., et al. (2001). Bone marrow cells regenerate infarcted myocardium. Nature 410, 701-705. doi: 10.1038/35070587

Piegari, E., Angelis, A., de, Cappetta, D., Russo, R., Esposito, G., Costantino, S., et al. (2013). Doxorubicin induces senescence and impairs function of human cardiac progenitor cells. Basic Res. Cardiol. 108:334. doi: 10.1007/s00395-013-0334-4

Popescu, L. M., Ciontea, S. M., Cretoiu, D., Hinescu, M. E., Radu, E., Ionescu, N., et al. (2005). Novel type of interstitial cell (Cajal-like) in human fallopian tube. J. Cell. Mol. Med. 9, 479-523. doi: 10.1111/j.1582-4934.2005.tb00376.x

Popescu, L. M., Gherghiceanu, M., Hinescu, M. E., Cretoiu, D., Ceafalan, L., Regalia, T., et al. (2006). Insights into the interstitium of ventricular myocardium: interstitial cajal-like cells (ICLC). J. Cell. Mol. Med. 10, 429-458. doi: 10.1111/j.1582-4934.2006.tb00410.x

Pouly, J., Bruneval, P., Mandet, C., Proksch, S., Peyrard, S., Amrein, C., et al. (2008). Cardiac stem cells in the real world. J. Thorac. Cardiovasc. Surg. 135, 673-678. doi: 10.1016/j.jtcvs.2007.10.024

Radu, E., Regalia, T., Ceafalan, L., Andrei, F., Cretoiu, D., and Popescu, L. M. (2005). Cajal-type cells from human mammary gland stroma: phenotype characteristics in cell culture. J. Cell. Mol. Med. 9, 748-752. doi: 10.1111/j.1582-4934.2005.tb00509.x

RajendranNair, D. S., Karunakaran, J., and Nair, R. R. (2017). Differential response of human cardiac stem cells and bone marrow mesenchymal stem cells to hypoxia-reoxygenation injury. Mol. Cell. Biochem. 425, 139-153. doi: 10.1007/s11010-016-2869-9

Rota, M., Kajstura, J., Hosoda, T., Bearzi, C., Vitale, S., Esposito, G., et al. (2007). Bone marrow cells adopt the cardiomyogenic fate in vivo. Proc. Natl. Acad. Sci. U.S.A. 104, 17783-17788. doi: 10.1073/pnas.0706406104

Rupp, S., Bauer, J., von Gerlach, S., Fichtlscherer, S., Zeiher, A. M., Dimmeler, S., et al. (2012). Pressure overload leads to an T increase of cardiac resident stem cells. Basic Res. Cardiol. 107:252. doi: 10.1007/s00395-012-0252-x

Sandstedt, J., Jonsson, M., Kajic, K., Sandstedt, M., Lindahl, A., Dellgren, G., et al. (2012). Left atrium of the human adult heart contains a population of side population cells. Basic Res. Cardiol. 107:255. doi: 10.1007/s00395-0120255-7

Sandstedt, J., Jonsson, M., Lindahl, A., Jeppsson, A., and Asp, J. (2010). Ckit+ CD45- cells found in the adult human heart represent a population of endothelial progenitor cells. Basic Res. Cardiol. 105, 545-556. doi: 10.1007/s00395-010-0088-1

Smith, R. R., Barile, L., Cho, H. C., Leppo, M. K., Hare, J. M., Messina, E., et al. (2007). Regenerative potential of cardiosphere-derived cells expanded from percutaneous endomyocardial biopsy specimens. Circulation 115, 896-908. doi: 10.1161/CIRCULATIONAHA.106.655209

Townsend, N., Nichols, M., Scarborough, P., and Rayner, M. (2015). Cardiovascular disease in Europe 2015: epidemiological update. Eur. Heart J. 36, 2673-2674. doi: 10.1093/eurheartj/ehv428 
Urbanek, K., Quaini, F., Tasca, G., Torella, D., Castaldo, C., Nadal-Ginard, B., et al. (2003). Intense myocyte formation from cardiac stem cells in human cardiac hypertrophy. Proc. Natl. Acad. Sci. U.S.A. 100, 10440-10445. doi: 10.1073/pnas.1832855100

Urbanek, K., Torella, D., Sheikh, F., Angelis, A., de, Nurzynska, D., Silvestri, F., et al. (2005). Myocardial regeneration by activation of multipotent cardiac stem cells in ischemic heart failure. Proc. Natl. Acad. Sci. U.S.A. 102, 8692-8697. doi: 10.1073/pnas.0500169102

Vicinanza, C., Aquila, I., Scalise, M., Cristiano, F., Marino, F., Cianflone, E., et al. (2017). Adult cardiac stem cells are multipotent and robustly myogenic: c-kit expression is necessary but not sufficient for their identification. Cell Death Differ. 24, 2101-2116. doi: 10.1038/cdd. 2017.130

World Medical Association. (1975). Declaration of Helsinki, 1st amendment.

Zhang, Y. Y., Li, G., Che, H., Sun, H. Y., Li, X., Au, W. K., et al. (2014). Characterization of functional ion channels in human cardiac ckit+ progenitor cells. Basic Res. Cardiol. 109:407. doi: 10.1007/s00395-0140407-z
Zhou, Y., Pan, P., Yao, L., Su, M., He, P., Niu, N., et al. (2010). CD117-positive cells of the heart: progenitor cells or mast cells? J. Histochem. Cytochem. 58, 309-316. doi: $10.1369 /$ jhc. 2009.955146

Conflict of Interest Statement: The authors declare that the research was conducted in the absence of any commercial or financial relationships that could be construed as a potential conflict of interest.

Maria Athelogou was employed by company Definiens AG, Munich, Germany. All other authors declare no competing interests.

Copyright (C) 2018 Gerisch, Smettan, Ebert, Athelogou, Brand-Saberi, Spindler, Mueller, Giri and Bader. This is an open-access article distributed under the terms of the Creative Commons Attribution License (CC BY). The use, distribution or reproduction in other forums is permitted, provided the original author(s) and the copyright owner are credited and that the original publication in this journal is cited, in accordance with accepted academic practice. No use, distribution or reproduction is permitted which does not comply with these terms. 